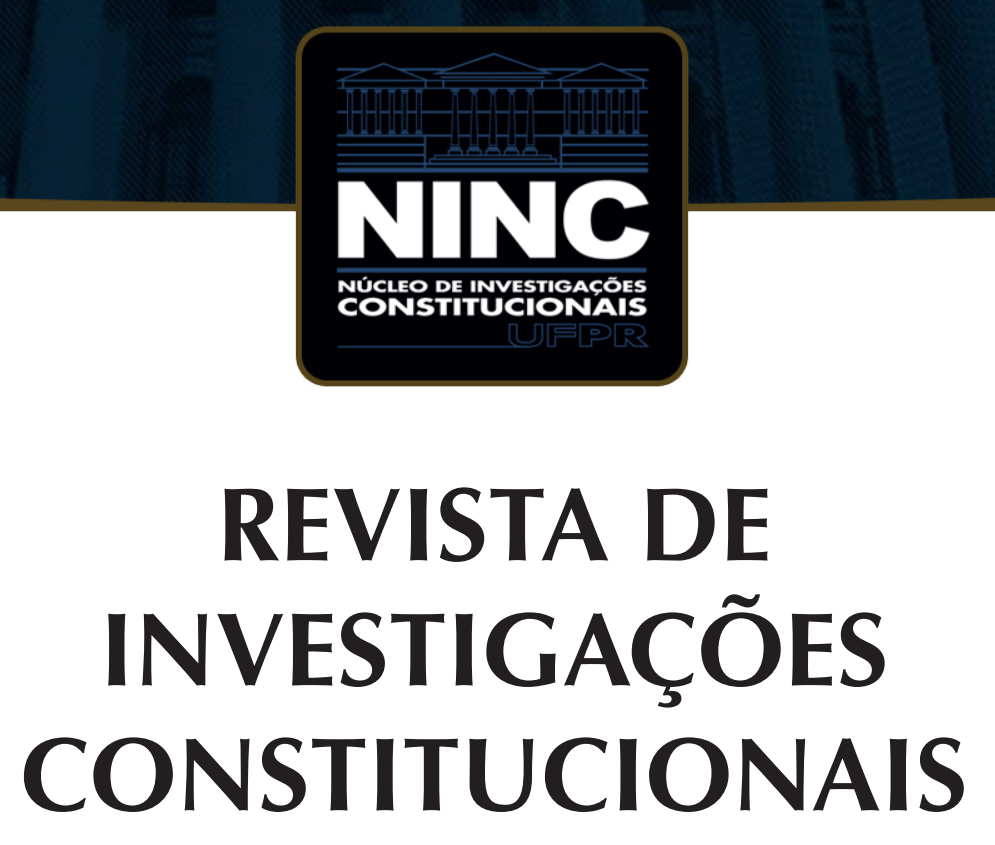

JOURNAL OF CONSTITUTIONAL RESEARCH

vol. 6 | n. 1 | janeiro/abril 2019 | ISSN 2359-5639 | Periodicidade quadrimestral Curitiba | Núcleo de Investigações Constitucionais da UFPR | www.ninc.com.br 


\title{
A nova cláusula de barreira e a sobrevivência das minorias
}

\section{The new barrier clause and the survival of minorities}

\author{
RAIMUNDO AUGUSTO FERNANDES NETO ${ }^{\mathrm{I}, *}$ \\ ${ }^{\mathrm{I}}$ Universidade de Fortaleza (Brasil) \\ ferrnandesnetoadv@hotmail.com \\ JÂNIO PEREIRA DA CUNHA ${ }^{\mathrm{II} \text {, ** }}$

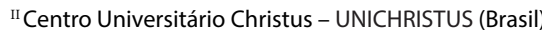 \\ janiopcunha@hotmail.com \\ Recebido/Received: 23.02 .2018 / February $23^{\text {th }}, 2018$ \\ Aprovado/Approved: 30.10 .2018 / October $30^{\text {th }}, 2018$
}

\section{Resumo}

Analisa a nova cláusula de barreira aprovada na Emenda Constitucional no 97/2017, que limita o acesso dos partidos políticos ao fundo partidário e ao programa gratuito de rádio e televisão, em virtude do percentual de votos mínimos recebidos nas eleições proporcionais à Câmara dos Deputados, ou, alternativamente, a eleição de 15 deputados federais distribuídos em um terço dos Estados. Averigua a incidência histórica da cláusula de desempenho no Brasil e nos sistemas proporcionais democráticos no Direito comparado. Utiliza-se de referências bibliográficas de teor clássico sobre os partidos políticos, democracia e Direito Eleitoral para questionar sua constitucionalidade. Projeta a incidência da nova emenda constitucional, com base nos elementos estatísticos fornecidos pelo Tribunal Superior Eleitoral das eleições gerais de 2014, comparativamente às

\section{Abstract}

The purpose of this article is to analyze the barrier clause approved in Constitutional Amendment 97/2017, which restricts the minority political parties's access to the public share funding and to the free political advertising time on radio and television, due failure to achieve a minimum percentage of votes in the proportional elections to the lower house, or alternatively, failure to elect a minimum of fifteen federal representatives distributed in one third of the States. This article also investigates the historical incidence of the electoral perfomance clause in Brazil, using classical bibliographical review on political parties, democracy and electoral law, in order to discuss its constitutionality. In sequence, this essay projects the impact of the new constitutional amendment, on the basis of statistical data provided by the Superior Electoral Court relating to the general elections of 2014, compared to the 2006 elections, when it

Como citar esse artigo/How to cite this article: FERNANDES NETO, Raimundo Augusto; CUNHA, Jânio Pereira da. A nova cláusula de barreira e a sobrevivência das minorias. Revista de Investigações Constitucionais, Curitiba, vol. 6, n. 1, p. 189-219, jan./ abr. 2019. DOI: 10.5380/rinc.v6i1.58085.

" Doutorando em Direito Constitucional pela Universidade de Fortaleza (Fortaleza-CE, Brasil). Mestre em Direito e Desenvolvimento pelo Centro Universitário Christus - UNICHRISTUS (Fortaleza-CE, Brasil). Especialista em Direito e Processo Eleitoral pela Universidade de Fortaleza. Especialista em Direito e Processo Penal pela Universidade de Fortaleza. Especialista em Direito e Processo Administrativo pela Universidade de Fortaleza Bacharel em Direito pela Universidade Federal do Estado do Ceará. Advogado. E-mail: fernandesnetoadv@hotmail.com

*** Professor do Programa de Pós-Graduação em Direito (Mestrado) do Centro Universitário Christus - UNICHRISTUS (Fortaleza-CE, Brasil). Professor do Curso de Direito da Universidade de Fortaleza (Fortaleza-CE, Brasil). Doutor e Mestre em Direito Constitucional pelo Universidade de Fortaleza (Fortaleza-CE, Brasil). E-mail: janiopcunha@hotmail.com. 
eleições gerais de 2006, empregada como referência na ADI no 1.351/DF do STF, que julgou inconstitucional a cláusula de barreira originária da Lei n 9.096/95. Conclui que a Emenda Constitucional no 97/2017, na parte que altera o $\S 3^{\circ}$ do art. 17 da Constituição Federal, viola a democracia brasileira que elegeu o sistema proporcional, o pluralismo político, o pluripartidarismo e a igualdade (de chances) como princípios, submetendo a risco a sobrevivência das minorias partidárias, pressuposto de um Estado Democrático de Direito, em benefício dos poderes estabelecidos.

Palavras-chave: cláusula de barreira; partidos políticos; pluralismo; pluripartidarismo; democracia. comes to the $A D I 1.351 / D F$, which ruled unconstitutional the original barrier clause insert in Law no. 9.096/95. The article concludes that constitutional amendment 97/2017, in the part that amends the third paragraph of article 17 of the national Constitution, represents a violation of Brazilian democracy as far as this has elected the electoral system of proportional representation, political pluralism, multiparty system and equal opportunities as fundamental principles. Therefore, the amendment would be jeopardizing the survival of minority parties, premise of the Democratic Rule of Law in favour of the established power.

Keywords: barrier clause; political parties; pluralism; multiparty; democracy.

\section{SUMÁRIO}

1. Introdução; 2. Democracia e Cláusula de barreira; 2.1 Democracia em crise; 2.2 Crise da representação política partidária; 2.3 Cláusula de barreira; 2.3.1 Cláusula de barreira no Brasil; 2.4 Emenda Constitucional no 97/2017; 2.4.1 Contexto político; 2.4.2 Contexto legislativo; 2.4.3 Contexto partidário; 2.5 Democracia brasileira: pluralismo político, pluripartidarismo e igualdade de chances; $\mathbf{3}$. Conclusão.

\section{INTRODUÇÃO}

Sob a bandeira de uma reforma indispensável à contenção de um estado de crise no Brasil - problema político com graves consequências econômicas, ou econômicas de consequências políticas - foram aprovadas alterações legislativas com repercussão no sistema político brasileiro de representação proporcional, entre as quais, a que instituiu uma cláusula de barreira ao funcionamento partidário.

A Emenda Constitucional (EC) n 97, de 4 de outubro de 2017, alterando o $\S$ $3^{\circ}$ do art. 17 da Constituição Federal, instituiu uma cláusula de desempenho que restringe o acesso ao fundo partidário e ao tempo de propaganda gratuito no rádio e na televisão às agremiações partidárias que, nas eleições para a Câmara dos Deputados, não atingirem três por cento do eleitorado, distribuídos em pelo menos um terço dos Estados, com, no mínimo, dois por cento de votos em cada um, ou, alternativamente, aos partidos que não elegerem 15 deputados federais, distribuídos, em pelo menos, um terço das unidades da Federação.

Concomitantemente, introduziram-se modificações no sistema de financiamento da política, de coligações proporcionais e de utilização do direito de antena, tendentes a exacerbar os efeitos da nova barreira partidária.

A instituição de cláusula de desempenho partidário não é uma novidade no sistema eleitoral brasileiro - apesar de nunca efetivada, tanto no período anterior ao marco da redemocratização, quanto sob a égide da nova ordem constitucional. O Supremo Tribunal Federal (STF), em pelo menos duas oportunidades, enfrentou concretamente 
a temática - pela última vez, no ano de 2006, na Ação Direta de Inconstitucionalidade - ADI no 1.531/DF, julgando-as inconstitucionais.

As barreiras partidárias são adotadas na maioria das democracias ocidentais que se utilizam do sistema proporcional de representação parlamentar, com as peculiaridades de cada realidade, mas geralmente destinadas a impedir o exercício do mandato dos partidos que não atingirem um percentual mínimo de votos, e não impeditivas do funcionamento partidário, especificidade brasileira.

A investigação tem como escopo aferir a compatibilidade da EC n 97/2017 com os princípios positivados na Carta Política de 1988, de modo especial, com o pluralismo político, o pluripartidarismo e a igualdade - elementos essenciais a um regime democrático - e perquirir se o contexto político, legislativo e partidário da integração normativa da nova cláusula de barreira seria significativo a ensejar uma revisão do precedente jurisprudencial firmado pelo STF.

Para tanto, tomaremos como auxílio as referências bibliográficas que enfocam, principalmente, a democracia, os partidos políticos e o Direito Eleitoral, além da investigação dos precedentes do Supremo Tribunal Federal. Com esteio nos números disponibilizados pelo Tribunal Superior Eleitoral, aplicaremos a nova cláusula de barreira aos resultados das eleições gerais de 2014, considerando as simulações realizadas no julgamento da ADI no 1.531/DF, relativo às eleições de 2006. Com base, também, nos resultados preliminares das eleição de 2018, faremos a aplicação do início da regra de transição, revelando os partidos excluídos pelo desempenho eleitoral do pleito recente.

A alteração constitucional da nova exigência de desempenho partidário foi aprovada no último round da reforma política e no prazo-limite de vigência, exigindo a imediata reflexão acadêmica e social, ante a ameaça à sobrevivência das minorias políticas, essenciais ao Estado Democrático de Direito.

\section{CLÁUSULA DE BARREIRA E DEMOCRACIA}

A cláusula de barreiras como limite ao exercício da representação política proporcional, que incide sobre as minorias, e a nova tentativa de sua implantação na política nacional atenderiam ao pluralismo político assegurado na Constituição Federal? No atual cenário estampando de crise democrática e partidária, seria constitucional e conveniente a limitação ao exercício partidário originada da Emenda Constitucional nº 97/2017? É o que se busca aferir no presente tópico.

\subsection{Crise da democracia}

Possivelmente, umas das expressões mais citadas, desde a academia aos mass media, é decerto a palavra crise. Crise política, moral, econômica, social, educacional, 
local, globalizada, humanitária e assim por diante. A crise é o estado natural e não tem mais característica de sazonalidade. $O$ estado de crise é inerente ao nosso tempo, epidêmico, próprio do mundo globalizado - sem fronteiras - onde problemas e informações se comunicam com a mesma velocidade - on-line.

A sensação é a de que o Estado não mais responde às garantias que prometeu ao cidadão no contrato social. O Estado não é responsivo aos anseios por segurança, saúde, educação, oportunidade de trabalho e seguridade garantidas ao cidadão, que restringiu sua liberdade, respeitando as leis e pagando tributos. É certo afirmar, com efeito, que sistemas políticos que "não funcionam bem - que são ineficazes no combate à pobreza e desigualdade, que são corruptos e ineficazes na redução do crime e dos quais o cidadão comum não se sente representado - engendram cidadãos que apresentam baixos níveis de apoio ao regime político".'

O braço do Leviatã ${ }^{2}$ já não alcança a maioria das pessoas, mas apenas uma elite privilegiada, política e econômica, aprofundando o fosso da desigualdade, dentro de uma sociedade que tem a isonomia como um dos princípios da democracia.

Como consequência natural, a classe dirigente, em especial nas democracias ocidentais, sofre com o desgaste da impotência do Estado. Já não pode atender as exigências da sociedade, mesmo com toda a tecnologia disponível.

Acentuado esse quadro de corrosão, os escândalos de corrupção permeiam os noticiários nacionais e internacionais. A convivência promíscua entre o proveito público e o interesse privado infirma a democracia representativa. Não é raro os políticos e a elite econômica se envolverem em interesses não republicanos.

O liame de confiança foi rompido. Não mais há identidade entre representantes políticos e representados; entre o Estado e o povo, que se recolhe à própria sorte e, em autodefesa, se prende ao individualismo, em atitude de isolamento, social e político, agravando o sentimento permanente de crise.

Aflora, com efeito, um fenômeno paradoxal: a política e sua representação institucional - os partidos - passaram a ser considerados como algo desprezível, atraindo um sentimento social de aversão ao que é político, que assim, decide em dissonância relativamente ao interesse público de quem representa.

Carlo Borboni, no livro "Estado de Crise", onde dialoga com o sociológico polonês Zigmunt Baumam alerta para essa ocorrência:

\footnotetext{
${ }^{1}$ RENNÓ, Lucio R.; SMITH, Amy E.; LAYTON, Matthew L.; PEREIRA, Frederico Batista. Legitimidade e qualidade da democracia no Brasil: uma visão da cidadania. São Paulo: Intermeios; Nashville: LAPOP, 2011. p. 29.

${ }^{2}$ Thomas Hobbes, em o Leviatã, 1592, usa a metáfora do monstro bíblico que representa o poder do soberano sobre seus súditos, que, naturalmente egoístas, se rendem ao contrato social. HOBBES, Thomas. Leviatã, ou, a matéria, forma e poder de um Estado eclesiástico e civil. Tradução de Rosina D’Angina. 3. ed. São Paulo: Ícone, 2008.
} 
A antipolítica assegura a continuação do jogo político em curso entre os partidos, pois o priva de significado social, já que o cidadão é obrigado a cuidar do seu próprio bem-estar: o Estado dirige e controla seus governados sem ser responsável por eles [...]. ${ }^{3}$

A crise é da democracia; do excesso de democracia; da garantia de liberdades demasiadas - dizem alguns mais céticos ${ }^{4}$. Emblemática a esse respeito é a afirmação sintética de Norberto Bobbio: "Nada ameaça mais matar a democracia que o excesso de democracia" ${ }^{5}$. A democracia, no entanto, exige um contínuo aperfeiçoamento, responsivo às necessidades da sociedade em movimento.

O conceito de democracia já não se prende à fase aristotélica, da Revolução Francesa ou do constitucionalismo estadunidense. Como um dever-ser, um ideal, projeta soluções a se estabelecerem com suporte na história aos desafios do presente, olhando para o futuro. Sua capacidade de mutação é confundida como estado permanente de crise. Norberto Bobbio arremata: "Para um regime democrático, o estar em transformação é seu estado natural: a democracia é dinâmica, o despotismo estático e sempre igual a si mesmo".6

Há como consequência do paradoxo mencionado o acionamento de certos mecanismos, historicamente renovados, de preservação da elite política. São criados desde medidas legislativas impeditivas do ato de renovar a representação política visando à manutenção das forças hegemônicas no poder e até o aparecimento de candidatos apolíticos ${ }^{7}$, como solução extravagante, que, em passado pouco remoto, povoaram os regimes de exceção.

Essa análise restringe-se a esses lindes legislativos impostos para a representação política partidária, como instrumento do exercício do poder e a necessária resposta democrática.

\footnotetext{
${ }^{3}$ BAUMAN, Zigmunt; BORDONI, Carlo. Estado de crise. Tradução de Renato Aguiar. Rio de Janeiro, Zahar, 2016, p. 26.

${ }^{4} \mathrm{O}$ cientista político e jornalista estadunidense Fareed Zakaria defende a ideia da supremacia do liberalismo constitucional sobre a democracia eleitoral no que chama lliberalismo:" [...]Conversely, the absence of free and fair elections should be viewed as one flaw, not the definition of tyranny. Elections are an important virtue of governance, but they are not the only virtue. Governments should be judged by yardsticks related to constitutional liberalism as well. Economic, civil, and religious liberties are at the core of human autonomy and dignity. If a government with limited democracy steadily expands these freedoms, it should not be branded a dictatorship." ZAKARI, Fareed. The rise of illiberal democracy. Disponível em: <https://www.foreignaffairs. com/articles/1997-11-01/rise-illiberal-democracy>. Acesso em: 13.08.2018.

${ }^{5}$ BOBBIO, Norberto. $O$ Futuro da democracia: uma defesa das regras do jogo. Tradução de Marco Aurélio Nogueira. 13. ed. São Paulo/Rio de Janeiro: Paz e Terra, 2015, p. 48.

${ }^{6}$ BOBBIO, Norberto. O Futuro da democracia: uma defesa das regras do jogo. Tradução de Marco Aurélio Nogueira. 13. ed. São Paulo/Rio de Janeiro: Paz e Terra, 2015, p. 23.

'Zigmunt Bauman adverte para o surgimento dos candidatos populistas: "Porém a antipolítica - conforme reconhecida por Balibar - resulta em populismo e nacionalismo, ambos sujeitos aos mais perigosos desvios. Com frequência ela se mostra o prelúdio de regimes tirânicos e autoritários, com demonstra a história recente". BAUMAN, Zigmunt; BORDONI, Carlo. Estado de crise. Tradução de Renato Aguiar. Rio de Janeiro: Zahar, 2016, p. 25.
} 


\subsection{Crise de representação político-partidária}

Como organizações burocráticas institucionalizadas, os partidos políticos só se firmaram desde o século XIX. ${ }^{8}$ São grandes estruturas, que exercem - ou buscam - o poder, tanto em regimes democráticos, como totalitários. Partido de esquerda, de direita, de centro, de extrema-direita, de extrema-esquerda, conservadores, trabalhistas, democratas, republicanos, socialistas, liberais, comunistas, ecológicos, religiosos, nacionalistas e assim continua uma série de denominações, demonstrando a identidade ideológica e programática partidária.

Marcos históricos como o capitalismo, a Revolução Francesa, o Constitucionalismo Estadunidenses, a Revolução Comunista na União Soviética, o regime nazista alemão e o fascismo de Mussolini planificaram as ideologias dessas associações políticas.

Apesar de guardarem características próprias, as agremiações partidárias professam, programaticamente, ideias universais, naturalmente, com variações. A socialdemocracia francesa não se assemelha à brasileira; os democratas ianques são mais progressistas do que os democratas brasileiros, mais à direita. Os comunistas brasileiros defendem um Estado Democrático de Direito.

Paulo Bonavides ${ }^{9}$ realça a via partidária como representatividade das massas:

O Estado social consagra, pois, corajosamente a realidade partidária. Tanto na democracia como na ditadura, o partido político é hoje o poder institucionalizado das massas. Forma, na imagem belissima de Sir Ernest Barker, aquela ponte ou canal, através da qual as correntes da opinião afluem da área da sociedade, onde nascem, para a área do Estado e suas instituições, onde afetam ou dirigem o curso da ação política.

O caráter ideológico dos partidos políticos, e mesmo a sua necessidade, permeiam a centralidade dos debates da democracia-crise. A práxis da política transcendeu a doutrina. As coligações partidárias e governos de coalisão, diametralmente contrários ao ideário político dos partidos, fragilizaram essa identidade. Passa-se a duvidar do clássico pensamento de Hans Kelsen ${ }^{10}$ "[...] somente a ilusão ou a hipocrisia podem fazer crer que a democracia é possível sem partidos políticos".

A crítica não é contemporânea. Robert Michels, no clássico Sociologia dos Partidos Políticos, do início do século XX, já reproduzia a queixa social que nominou de "Lei de Ferro da Oligarquia". Michels, ao tempo, se reportava, inicialmente, à elite do Partido Social democrata Alemão, que, originária da classe operária, se tornou oligárquica,

${ }^{8}$ AZAMBUJA, Darcy. Teoria Geral do Estado. 44. ed. São Paulo: Globo, 2005, p. 345-351; CAETANO, Marcello. Manual de Ciência Política e Direito Constitucional. 6. ed., rev. e ampl. Lisboa: Almedina, 2009, t. I, p. 377405.

${ }^{9}$ BONAVIDES, Paulo. Ciência Política. 10. ed. São Paulo: Malheiros, 2000, p. 359.

${ }^{10}$ KELSEN, Hans. A democracia. Tradução de Ivone Castilho Benedetti, Jeferson Luís Camargo, Marcelo Brandão Cipolla e Vera Barkow. 2. ed. São Paulo: Martins Fontes, 2000, p. 35. 
segundo sua óptica. Expressa Michels ${ }^{11}:$ "[...] a organização é a fonte onde nasce a dominação dos eleitos sobre os eleitores, dos mandatários sobre os mandantes, dos delegados sobre os que delegam. Quem diz organização, diz oligarquia".

Não por acaso, os partidos são tidos como um dos fatores responsáveis pela crise democrática. O instrumento de condução da vontade do povo, por delegação, quase sempre é oligárquico, antidemocrático, inapto a estabelecer um governo da maioria, pois reflete apenas a vontade da classe dirigente. Com poucas exceções, são oligarquias partidárias familiares, de classe e econômicas. Propriedades de poucos, esqueceram suas bases políticas e ideológicas, se é que ainda as têm. A mobilidade é insignificante e, quando existente, é consentida pela cúpula dirigente.

O Brasil não destoa dessa realidade. Acrescentamos, aqui, o agravante das contumazes transferências partidárias. A democracia interna é estreita, e, havendo dissenso, o filiado adere à nova agremiação. A proliferação de partidos é consequente desta equação e não da diversidade de ideias. A simples experiência de prévias partidárias, raramente é exercida internamente nos partidos brasileiros ${ }^{12}$, ficando a definição das candidaturas restrita à escolha dos dirigentes, projetando uma falsa ideia de coesão.

Luigi Ferrajoli adverte para gravidade da crise ao se debruçar sobre a democracia italiana, na era Silvio Berlusconi ${ }^{13}$. Propõe soluções drásticas:

A crise dos partidos originada pela transformação dos grupos dirigentes em castas privilegiadas separadas das suas bases sociais é, portanto, tão grave que, se não se quer que seja abatida a democracia política, não pode ser superada a não ser com reformas radicais: primeira dentre todas aquelas já ilustrada da incompatibilidade entre cargos de partido e cargos institucionais que certamente teria o efeito de eliminar o interesse pessoal na autocandidatura e de restituir o partido ao seu papel constitucional de organização "de baixo" da participação dos cidadãos na vida política. ${ }^{14}$

\footnotetext{
${ }^{11}$ MICHELS, Robert. A Sociologia dos partidos políticos. Tradução de Arthur Chaudon Brasília: UNB, 1982, p. 238.

${ }^{12} \mathrm{Na}$ história recente da democracia brasileira, só tivemos uma prévia partidária ocorrida em eleições gerais, em 2002 no Partido dos Trabalhadores (PT), entre Lula x Suplicy. Para a Prefeitura de São Paulo, as prévias ocorreram em 1988 - PT, entre Luíza x Plínio de Arruda Sampaio; em 2012, entre José Serra x Ricardo Trípoli x José Aníbal, do PSDB, e 2016, entre João Dória x Matarazzo x Ricardo Trípoli. E para Prefeitura do Recife em 2012, entre Rands x João da Costa, do PT.

${ }^{13}$ Sílvio Berlusconi foi o bilionário ex-primeiro ministro italiano, que governou a Itália dos anos de 1994-2011, concentrando o poder político e econômico e o controle da informação, pois proprietário de um poderoso conglomerado de comunicação de massa, além de dono do Milan, uma das mais populares equipes de futebol da Itália. Luigi Ferrajoli denominou essa concentração de Poderes Selvagens.

${ }^{14}$ FERRAJOLI, Luigi. Poderes selvagens: A crise da democracia italiana. Tradução de Alexandre Araújo de Sousa. São Paulo: Saraiva. 2014, p. 65.
} 
A democracia participativa ${ }^{15}$ é apontada como solução e modelo para refundar a representação autêntica dos anseios da população, contrariada pela política profissional que vive da política e não para a política, na distinção de Max Weber ${ }^{16}$. Vivendo da política buscam os próprios interesses e, para política, almejam o proveito comum, não tendo a política como objetivo pessoal, profissional e fim em si mesmo.

Os partidos políticos são essenciais para a democracia e o viés ideológico ainda não se perdeu, mormente quando estão fora do poder, e tendem a se agregar. Uma democracia com mais participação popular é o novo (velho) desafio democrático.

As oposições das oligarquias partidárias às mudanças são constantes e tendentes a limitar maior inclusão democrática. A manutenção do statu quo é o que interessa. O controle do sufrágio universal já seria suficientemente intrusivo na autonomia partidária para escolher os representantes. Luís Felipe Miguel ${ }^{17}$ comenta a prática aristocrática eleitoral:

Na prática política, os cidadãos comuns não escolhem um representante para promover seus interesses, formulação que Ihes concede papel ativo. Ao contrário, eles apenas reagem diante das ofertas que o mercado político apresenta.

O artigo sob relatório analisa a compatibilidade democrática e constitucional de um desses mecanismos legislativos de limitação da democracia participativa, recentemente renovado no Brasil junto à reforma constitucional de 2017: a cláusula de barreira.

\subsection{Cláusula de barreira}

O conceito da democracia foi modificando ao longo da história, transpondo o "governo do povo", originário da Grécia Antiga. Desde o advento do constitucionalismo estadunidense e da Revolução Francesa com ideias liberais - Igualdade, Liberdade e Fraternidade - a democracia não significa apenas o governo da maioria, mas,

\footnotetext{
${ }^{15}$ Yves Sintomer enfrenta o tema da democracia participativa na obra O Poder ao Povo: Júris de cidadãos, sorteio e democracia participativa - asseverando que "O objetivo disso é estabelecer uma verdadeira democracia participativa, capaz de romper com o monopólio dos representantes eleitos sobre a definição do interesse geral, sem sucumbir à democracia midiática ou se perder nos meandros de uma "governança" exercida por grupos de interesses controlados". SINTOMER, Yves. O Poder ao povo: júris de cidadãos, sorteio e democracia participativa. Tradução de André Rubião. Belo Horizonte: UFMG, 2010, p. 168.

${ }^{16}$ Max Weber, na obra A Política como vocação, refuta o interesse pessoal do político: "Quem vive para a política a torna o fim de sua existência, ou porque essa atividade permite obter no simples exercício do poder, ou porque mantém seu equilíbrio interior e sua autoestima fundados na consciência de que sua existência tem sentido à medida que está à serviço de uma causa. Num sentido profundo, todo aquele que vive para uma causa vive dela também. É o aspecto econômico um dos elementos importantes da condição do homem político. O que vê na política uma fonte permanente de rendas, vive da política como vocação; no caso oposto, vive-se para a política". WEBER, Max. A Política como vocação. Tradução de Mauricio Tragtenberg. Brasília: Universidade de Brasília, 2003, p. 22-23.
}

${ }^{17}$ MIGUEL, Luís Felipe. Democracia e representação: territórios em disputa. São Paulo: Unesp, 2014, p. 117. 
sobretudo, o respeito ao direito das minorias. Sartori ${ }^{18}$, ao citar Lord Acton, adverte que "o teste mais seguro para julgarmos se um país é realmente livre é o grau de segurança desfrutado pelas minorias". Portanto, a ditadura da maioria deve ser evitada tanto quanto uma "guardiania"19. A propósito da questão, Tocqueville ${ }^{20}$ prescrevia: “E só sei de um meio para impedir que os homens se degradem: não conceder a ninguém, com a onipotência, o poder soberano de aviltá-los".

Para preservar a expressão das minorias no regime democrático, criou-se o sistema de representação proporcional ${ }^{21}$, que, como leciona Paulo Bonavides ${ }^{22}$, “[...] é o sistema que confere às minorias igual ensejo de representação de acordo com sua força quantitativa". O sistema proporcional assegura ao pensamento minoritário, organizado partidariamente, representação política na medida de sua corporificação eleitoral, deficitária no sistema das maiorias - majoritário.

Ocorre que uma das críticas ao sistema proporcional é a fragmentação demasiada do poder, que impossibilitaria um governo eficiente. A influência da minoria também teria consequências deletérias ao princípio da justiça representativa, "[...] fazendo de partidos insignificantes os donos do poder"23, quando indispensáveis à formação de uma maioria.

Como antídoto a esse esfacelamento da representação, em grande parte das sociedades democráticas, foram inseridas cláusulas eleitorais de desempenho, visando a limitar a participação minoritária. No caso brasileiro, existem a adoção do coeficiente eleitoral ${ }^{24}$ e restrições ao exercício e funcionamento partidário - acesso a financiamento público e outras restrições - revitalizadas, recentemente, mediante adição ao texto constitucional.

A cláusula de barreira existe em grande parte nos países que utilizam sistema de representação proporcional, puro ou misto. Talvez a mais emblemática seja a prevista na legislação alemã ${ }^{25}$, que exige o percentual de $5 \%$ dos votos, para que o partido te-

\footnotetext{
${ }^{18}$ SARTORI, Giovanni. A teoria da democracia revisitada: o debate contemporâneo. V. 1. São Paulo: Ática, 1994, p. 54. ${ }^{19}$ Segundo Robert Dahl a "guardiania" pressupõe que "[...] rulership should be entrusted to a minority of persons who are specially to govern by reason of their superior knowledge and virtue. DAHL, Robert A. Democracy e and its critics. New Haven and London: Yale University Press, 1989, p. 52.

${ }^{20}$ TOQUEVILLE, Alexis de. A democracia na América: leis e costumes de certas leis e certos costumes políticos que foram naturalmente sugeridos aos americanos por seu estado social e cronologia de François Furet. Tradução de Eduardo Brandão. V. I. 2. ed. São Paulo: Martins Fontes, 2005, p. 303.

${ }^{21} \mathrm{O}$ modelo de representação proporcional foi utilizado pela primeira vez na Bélgica nas eleições legislativas nacionais de 1899. Em 1888, ocorreu na Bélgica a Conferência Internacional de Reforma Eleitoral, com participantes europeus, que aderiram ao modelo Victor D'Hondt, publicado em 1882 - Sistema Racional e Prático de Representação.

${ }^{22}$ BONAVIDES, Paulo. Ciência Política. 10. ed. São Paulo: Malheiros, 2000, p. 324.

${ }^{23}$ BONAVIDES, Paulo. Ciência Política. 10. ed. São Paulo: Malheiros, 2000, p. 324.

${ }^{24} \mathrm{O}$ Código Eleitoral estabelece nos artigos 106 a 113 o sistema de coeficiente eleitoral.

${ }^{25}$ Para melhor entender o sistema alemão de votos, consultar: PONTES, Roberto Carlos Martins; HOLTHE, Leo Oliveira Van. O Sistema Eleitoral Alemão pós a Reforma de 2013 e a viabilidade de sua adoção no Brasil.
} 
nha acesso ao Bundestag. Somente $50 \%$ das vagas são preenchidas proporcionalmente, por meio de listas elaboradas pelos partidos (fechadas) - onde os partidos indicam um ranqueio ordenado de candidatos. As vagas restantes são preenchidas por meio de sistema distrital (majoritário). Vota-se, pois, duas vezes: uma no sistema proporcional e outra no candidato do distrito do eleitor.

Alternativamente, o sistema permite o acesso ao Legislativo, independentemente do percentual de votos obtidos proporcionalmente, caso o partido eleja, até três representantes distritais, dos 16 existentes.

Seguindo o modelo germânico ${ }^{26}$, outros regimes democráticos estabeleceram restrições semelhantes, com variações percentuais e regras próprias. Na Argentina, o padrón electoral, são três por cento; na Itália, quatro por cento; na Suécia, quatro por cento; na Nova Zelândia, são cinco por cento e na Espanha, de três, nas eleições distritais, a cinco por cento, nas municipais.

O Brasil não ficou à margem das restrições ao exercício partidário. Ao longo da experiência democrática, algumas vezes interrompidas por períodos de exceção, como veremos, também foram estabelecidos limites ao exercício partidário e ao acesso aos mandatos legislativos.

\subsubsection{Cláusulas de barreira no Brasil antes da Constituição de 1988}

No Brasil, a tentativa da imposição legal das cláusulas de barreira teve início em 1946, com o Decreto-Lei n 8.835 , que exigiu, sob pena de cassação dos partidos políticos, que estes tivessem quantidade igual ou superior de votos aos números de eleitores com os quais formalizaram seu registro definitivo.

O Decreto-Lei no 8.835/46, de 24 de janeiro de 1946, sequer teve efetividade quanto a sua cláusula de desempenho partidário, pois logo foi revogado pelo Decreto n० 9.258, de 24 maio de 1946, passando a estabelecer limites de associados para criação de partidos políticos. No artigo 40, fixou a regra de transição para continuidade dos partidos em funcionamento, exigindo que houvesse representantes na Assembleia

Consultoria Legislativa, abril/2015. Disponível em: <http://www2.camara.leg.br/a-camara/documentos-e-pesquisa/estudosnotas-tecnicas/areas-da-conle/tema6/2015_1531-sistema-eleitoral-alemaoleo-van-holthe-e-roberto-pontes>. Acesso em: 26 out. 2017.

${ }^{26}$ O Tribunal Constitucional Alemão relativizou a regra quando a aplicação se destinava às Eleições do Parlamento Europeu. Em 9 de novembro 2011, o segundo Senado do Bundesverfassungsgericht julgou inconstitucional (2 BvC 4/10) a exigência contida do § 2.7 do Atos da Eleições Europeias, que exigiu, de igual forma a legislação da Alemanha, uma cláusula de barreira de $5 \%$ para eleições dos membros do Parlamento Europeu em 2009, por considerar violado o princípio da igualdade do voto e da oportunidade de representação partidária. A repercutida decisão foi tomada por maioria de cinco votos contra três. BUNDESVERFASSUNGSGERICHT. Five per cent barrier clause in the law governing the European elections held unconstitutional. Disponível em <https://www.bundesverfassungsgericht.de/SharedDocs/Pressemitteilungen/EN/2011/bvg11-070.html>. Acesso em: 08 fev. 2018. 
Constituinte eleita em dezembro de 1945, ou, ainda, amealhado o mínimo de 50 mil votos, em pelo menos cinco circunscrições eleitorais.

No que se refere à Lei n 1.164, de 24 de julho de 1950 - Código Eleitoral de 1950, repetiram-se os critérios utilizados pela regra de transição da lei anterior, quando, no artigo 148, exigiu, sob pena de cancelamento, que o partido viesse a eleger, pelo menos, um representante no Congresso Nacional ou alcançar, em todo o país, cinquenta mil votos sob legenda.

No regime político de exceção decorrente do golpe de 31 de março de 1964, ainda no início, sob a promessa militar de breve restabelecimento democrático, editou-se a Lei n 4.740, de 15 de julho de 1965, criando a Lei Orgânica dos Partidos Políticos, prevendo restrições ao funcionamento das agremiações partidárias, que deveriam contar com o apoio de três por cento do eleitorado votante nas últimas eleições gerais, em pelo menos 11 Estados, com mínimo de dois por cento por Unidade Federada (U.F.).

Outro ponto a se destacar foi a possibilidade de extinção dos partidos, então existentes, prevista no artigo 47 da mesma legislação, que não comprovassem ter diretórios regionais em 11 Estados; 12 deputados federais eleitos, em pelo menos 7 Estados; e, por derradeiro, o voto em legenda partidária de três por cento do eleitorado brasileiro, em eleições gerais parlamentares. A Lei Orgânica dos Partidos Políticos objetivava restringir drasticamente o número de partidos, que findaram com o Ato Institucional $\mathrm{n}^{\circ} 2(\mathrm{Al}-2)^{27}$.

A Constituição de 1967, convocada pelo Ato Institucional no 4 (Al-4) do governo militar do presidente Castello Branco, restringiu drasticamente os direitos sociais e políticos, e serviu para legitimar o governo autoritário. Uma das rigorosas limitações políticas foi a fixação, no âmbito constitucional, de cláusula de barreira, prevista no artigo no 149, com a necessidade de dez por cento de votos, distribuídos em dois terços dos Estados, como o mínimo de sete por cento para cada um deles, além do mínimo de dez por cento de deputados e senadores.

Na Emenda Constitucional no 1, de 1969, a exigência de dez por cento, anteriormente prevista no texto original, foi reduzida para cinco por cento, com distribuição, em 7 Estados, com, no mínimo, sete por cento por unidade federada.

Já na era Geisel (1974-1979) do regime castrense, foi aprovada a Emenda Constitucional no 11, de 1978, revogando algumas limitações, entre as quais os atos institucionais, reestabelecendo o Habeas corpus, no entanto, adicionando a cláusula de desempenho para distribuir os cinco por cento de votos necessários em 9 Estados, com o mínimo de três por cento em cada qual.

\footnotetext{
${ }^{27}$ Para melhor entender os partidos políticos durante o regime militar, consultar o artigo de Sérgio Lamarão, intitulado "Partidos Políticos (Extinção)". Disponível em: <http://www.fgv.br/cpdoc/acervo/dicionarios/verbete-tematico/partidos-politicos-extincao>. Acesso em: 26 out. 2017.
} 
Na fase de abertura política, anterior à redemocratização, foi aprovada a Emenda Constitucional n²5/85, alterando o índice de desempenho para o funcionamento parlamentar, para três por cento do total dos votos, distribuído em 9 Estados da Federação, com percentual mínimo de dois por cento por U.F.

Essa teria sido a última fixação de cláusula de desempenho em texto constitucional, se não fora a Emenda Constitucional n 97, de 2017.

\subsubsection{Cláusula de barreira na ordem constitucional de 1988}

Na Constituição de 1988, o legislador brasileiro, deliberadamente, extirpou do Texto Constitucional as cláusulas de desempenho partidário. Não o fez por omissão, nem delegou à norma infraconstitucional, mas por escolha. Atuou contraposto à Constituição de 1967, então vigente, que a previa desde o texto original. Assere Ricardo Rodrigues ${ }^{28}$ que "[...] os constituintes deixaram bem clara sua opção contrária à inserção, com a omissão deliberada de tais exigências".

Expressamente a Constituição de 1988 elegeu o pluralismo político, dentre seus fundamentos (art.1 $\left.{ }^{\circ}, \mathrm{V}\right)$, garantindo o pluripartidarismo consoante se extrai do artigo 17. Não nos parece haver esquecimento do legislador constitucional originário. Houve, de fato, firme atuação destinada a barrar as cláusulas de desempenho partidário.

Antes mesmo da Revisão Constitucional prevista para 1993, foi aprovada a Lei n० 8.713, de 30 de setembro de $1993^{29}$, fixando as normas para as eleições gerais de 1994, com uma série de exigências de desempenho eleitoral para os partidos que pretendiam lançar candidato a Presidente da República, governador e senador. Para Presidente, a exigência foi de cinco por cento dos votos apurados na eleição de 1990,

${ }^{28}$ RODRIGUES, Ricardo. Barreira legal nos sistemas eleitorais proporcionais. Revista de Informação Legislativa. V. 32, n. 126, p. 47-55, abr./jun.1995. Disponível em: <http://www2.senado.leg.br/bdsf/item/id/176321>. Acesso em: 28 out. 2017, p. 52

${ }^{29}$ Art. $5^{\circ}$ - Poderá participar das eleições previstas nesta lei o partido que, até 3 de outubro de 1993, tenha obtido, junto ao Tribunal Superior Eleitoral, registro definitivo ou provisório, desde que, neste último caso, conte com, pelo menos, um representante titular na Câmara dos Deputados, na data da publicação desta lei. § 1 ○ Só poderá registrar candidato próprio à eleição para Presidente e Vice-Presidente da República:

I - O partido que tenha obtido, pelo menos, cinco por cento dos votos apurados na eleição de 1990 para a Câmara dos Deputados, não computados os brancos e os nulos, distribuídos em, pelo menos, um terço dos Estados; ou

II - o partido que conte, na data da publicação desta lei, com representantes titulares na Câmara dos Deputados em número equivalente a, no mínimo, três por cento da composição da Casa, desprezada a fração resultante desse percentual; ou

III - coligação integrada por, pelo menos, um partido que preencha condição prevista em um dos incisos anteriores, ou por partidos que, somados, atendam às mesmas condições.

$\S 2 \circ$ Só poderá registrar candidatos a Senador, Governador e Vice-Governador:

I - o partido que tenha atendido a uma das condições indicadas nos incisos I e II do parágrafo anterior; ou II - o partido que, organizado na circunscrição, tenha obtido na eleição de 1990 para a respectiva Assembleia ou Câmara Legislativa três por cento dos votos apurados, excluindo os brancos e nulos; ou III - coligação integrada por, pelo menos, um partido que preencha uma das condições previstas nos incisos I e II deste parágrafo, ou por partidos que, somados, atendam às mesmas condições. 
distribuídos em pelo menos um terço dos Estados, ou que, na data da publicação da lei, houvesse pelo menos três por cento dos membros da Câmara dos Deputados. Condições semelhantes, com percentual de três por cento, foram impostas aos governadores e senadores.

As previsões contidas no artigo $5^{\circ}$, $\S \S 1^{\circ}$ e $2^{\circ}$, da Lei no 8.713/93, foram questionadas no STF por meio da ADI no 966/DF, ajuizada em 25 de outubro de 1993, relatada pelo min. Marco Aurélio de Mello. No julgamento, ocorrido em 11 de maio de 1994, ficou assentado a inconstitucionalidade dos referidos dispositivos, tanto pelo fato de, ao tempo da norma, já se conhecer quais as agremiações partidárias estariam impedidas de participarem do pleito, como pela escolha da Constituição de 1988 em garantir a plena participação da minoria em contraposição à Constituição de $1967^{30}$.

A cláusula de barreira voltou à discussão em 1993, na Revisão Constitucional prevista pelo legislador originário de 1988, no artigo $3^{\circ}$ do Ato das Disposições Constitucionais Transitórias (ADCT). A despeito da discussão política e jurídica dos limites revisionais $^{31}$, que não poderiam ir além da consulta plebiscitária ${ }^{32}$ sobre a modalidade e o sistema de governo, ocorrido em 21 de abril de 1993, foram discutidas várias alterações no texto constitucional, entre as quais, a do retorno do patamar eleitoral.

O relator da Revisão Constitucional - Nelson Jobim - emitiu o Parecer no 36, visando a alterar o artigo 17 da Constituição, propondo o restabelecimento da cláusula de barreira, de cinco por cento dos votos, em pelo menos um terço dos Estados, com o mínimo de dois por cento em cada U.F. O Parecer sequer foi objeto de apreciação pelo Congresso Revisor. Mais uma vez optou-se pela exclusão das cláusulas de desempenho.

Novamente o tema veio a lume com a aprovação da Lei no 9.096/95 - Lei dos Partidos Políticos - regulamentando o art.17, IV da Constituição Federal. A cláusula de barreira foi retomada, desta feita, a fim de exigir, para funcionamento parlamentar, os cinco por cento dos votos nas eleições gerais, em pelo menos um terço dos Estados,

\footnotetext{
${ }^{30}$ Veja a Ementa: PARTIDOS POLÍTICOS- INDICAÇÃO DE CANDIDATOS - RESSUPOSTOS - INCONSTITUCIONALIDADE. Exsurgem conflitantes com a Constituição Federal os preceitos dos $\S \S 1^{\circ} \mathrm{e} 2^{\circ}$ do artigo $5^{\circ}$ da Lei no $8.713 / 93$, no que vincularam a indicação de candidatos à Presidente e Vice-Presidente da República, Governador e Vice-Governador e Senador a certo desempenho do Partido Político no pleito que a antecedeu e, portanto, dados fáticos conhecidos. A Carta de 1988 não repetiu a restrição contida no artigo 152 da pretérita, reconhecendo, assim, a representação dos diversos segmentos sociais, inclusive os que formam dentre as minorias. BRASIL. Supremo Tribunal Federal. Acordão no 966/DF. Disponível em: <http://redir.stf.jus.br/paginadorpub/ paginador.jsp?docTP=AC\&doclD=266603>. Acesso em: 30 out. 2017.

${ }^{31}$ Sobre a discussão dos limites da revisão constitucional de 1993, consultar o artigo de Geraldo Ataliba, que restringia a revisão dentro dos limites do plebiscito de forma e sistema de governo. (ATALIBA, 1993). Disponível em: $<$ http://www2.senado.leg.br/bdsf/bitstream/handle/id/176159/000482857.pdf?sequence=3>. Acesso em: 30 nov. 2017.

${ }^{32}$ No dia 21 de abril de 1993, foi realizado no Brasil um plebiscito para forma e sistema de governo, sendo mantida a república $(86,6 \%)$ e o presidencialismo $(69,2 \%)$ com expressiva maioria dos votos válidos.
} 


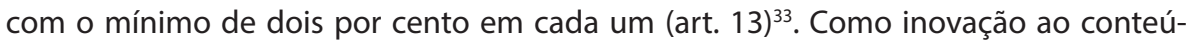
do das normas anteriores, restringiu-se o acesso ao fundo partidário ${ }^{34}$, como também sobejou restrito o acesso ao programa eleitoral gratuito ${ }^{35}$, com base nos parâmetros previstos no artigo 13, do citado diploma.

As limitações prescritas nos artigos 13, 41, 48, 56 e 57 da Lei dos Partidos Políticos foram objeto de duas ações diretas de inconstitucionalidade - ADIs no 1.351/DF e n० 1.354/DF - propostas por partidos minoritários entre os quais: Partido Democrático Trabalhista; Partido Popular Socialista; Partido Comunista do Brasil e Partido Social Cristão, ainda no ano de 1995, e somente julgadas em 07 de dezembro de 2006, em face da previsão para funcionamento nas eleições de 2007.

As arguições de inconstitucionalidade foram julgadas procedentes, à unanimidade, segundo o voto do relator - min. Marco Aurélio de Mello. Confira-se, a esse respeito, parte da ementa a seguir transcrita:

Surge conflitante com a Constituição Federal lei que, em face da gradação de votos obtidos por partido político, afasta o funcionamento parlamentar e reduz, substancialmente, o tempo de propaganda partidária gratuita e a participação no rateio do Fundo Partidário. $^{36}$

O julgamento do Órgão Pleno do STF serviu para reafirmar o posicionamento anterior, garantindo o funcionamento das minorias parlamentares, contando com votos relevantes, destacando-se o do min. relator - Marco Aurélio de Mello - e do min. Gilmar Mendes, que analisa o assunto à luz do exemplo alemão. Esse paradigma é necessário ao debate que se exprime, com o evento limitante da atuação partidária aprovada pela Emenda Constitucional n 93/2017, para vigorar nas eleições gerais seguintes às de 2018.

\footnotetext{
${ }^{33} \mathrm{Art}$. 13. Tem direito a funcionamento parlamentar, em todas as Casas Legislativas para as quais tenha elegido representante, o partido que, em cada eleição para a Câmara dos Deputados obtenha o apoio de, no mínimo, cinco por cento dos votos apurados, não computados os brancos e os nulos, distribuídos em, pelo menos, um terço dos Estados, com um mínimo de dois por cento do total de cada um deles.

${ }^{34} \mathrm{Art}$. 41. O Tribunal Superior Eleitoral, dentro de cinco dias, a contar da data do depósito a que se refere o $\S 1^{\circ}$ do artigo anterior, fará a respectiva distribuição aos órgãos nacionais dos partidos, obedecendo aos seguintes critérios.

I- um por cento do total do Fundo Partidário será destacado para entrega, em partes iguais, a todos os partidos que tenham seus estatutos registrados no Tribunal Superior Eleitoral;

II - noventa e nove por cento do total do Fundo Partidário serão distribuídos aos partidos que tenham preenchido as condições do art. 13, na proporção dos votos obtidos na última eleição geral para a Câmara dos Deputados.

${ }^{35}$ Art. 48. O partido registrado no Tribunal Superior Eleitoral que não atenda ao disposto no art. 13 tem assegurada a realização de um programa em cadeia nacional, em cada semestre, com a duração de dois minutos.

${ }^{36}$ BRASIL, Supremo Tribunal Federal. Acórdão $n^{\circ}$ 1.351/2007. Disponível em: <http://redir.stf.jus.br/paginadorpub/paginador.jsp?docTP=AC\&docID=416150>. Acesso em: 30 nov. 2017.
} 


\subsection{Emenda Constitucional $n^{\circ} 97 / 2017$}

A aprovação da EC n 97/2017 se deu em momento político conflituoso. A pressão popular por reformas e o número sem precedentes de agremiações motivaram a criação da cláusula de desempenho. A análise do contexto legislativo, político e partidário da alteração constitucional é necessária para o entendimento das consequências dessa implantação no sistema eleitoral brasileiro.

\subsubsection{Contexto político}

Em meio a uma crise política e econômica sem precedentes, desde a última redemocratização nacional, o único consenso entre as forças políticas era a necessidade de uma reforma política.

O Brasil dividiu-se com as eleições presidenciais de 2014. A vitória da chapa PT/ PMDB $^{37}$, composta por Dilma Rousseff e Michel Temer, com 51,64\% dos votos válidos, contra 48,36\% de Aécio Neves/Aluísio Nunes, do PSDB, não arrefeceu o acirramento político.

Logo após, a Presidente Dilma Rousseff perdeu a maioria de sua base parlamentar e foi submetida a um processo de impedimento por crime de responsabilidade política, resultando, inicialmente, em afastamento, e, posteriormente, na perda de mandato, por 60 votos contra 20 no Senado Federal. ${ }^{38}$

Tramitavam no Tribunal Superior Eleitoral (TSE) ações eleitorais (AIJE nº 194358, AIME n० 761 e RP n० 846) ${ }^{39}$ que visavam à cassação dos mandatos e à decretação de inelegibilidade da coligação vitoriosa - Dilma e Temer. O maior interessado no julgamento era Michel Temer, que se encontrava na Presidência, sendo inocentado pela maioria de quatro votos a três dos membros do TSE, em julgamento em que foram desconsideradas provas de doações financeiras sem contabilização oficial.

Registremos o fato de que, concomitantemente aos episódios relatados, se desenvolvia uma série de escândalos políticos que revelavam, a cada noticiário, uma promíscua relação entre o público e o privado. "Lava Jato" e "JBS" são exemplos de operações criminais que envolvem membros dos maiores partidos políticos brasileiros. Segundo levantamento feito pela Deutsche Welle Brasil - agência alemã de notícias

\footnotetext{
${ }^{37} \mathrm{O}$ resultado geral das eleições presidenciais encontra-se disponível em: <http://www.tse.jus.br/imprensa/ noticias-tse/2014/Dezembro/plenario-do-tse-proclama-resultado-definitivo-do-segundo-turno-da-eleicao-presidencial>. Acesso em: 6 nov.2017

${ }^{38}$ Sobre o Impeachment de Dilma Rousseff, ver: <https://www12.senado.leg.br/noticias/materias/2016/12/28/ impeachment-de-dilma-rousseff-marca-ano-de-2016-no-congresso-e-no-brasil>. Acesso em: 6 nov. 2017.

${ }^{39}$ AIJE significa Ação de Investigação Judicial Eleitoral; AIME, Ação de Impugnação de Mandato Eletivo e RP, Representação Eleitoral, que postulam a cassação de registros, diplomas e mandatos na Justiça Eleitoral. Veja o resultado do julgamento no TSE no sítio <http://www.tse.jus.br/imprensa/noticias-tse/2017/Junho/por-4-;votos-a-3-plenario-do-tse-decide-pela-nao-cassacao-da-chapa-dilma-e-temer>. Acesso em: 6 nov. 2017.
} 
internacionais - tramitam no STF cerca de 500 procedimentos criminais (processos e inquéritos) contra membros do Congresso Nacional. ${ }^{40}$

O presidente Michel Temer se inclui nesta estatística, e teve contra si duas denúncias criminais propostas junto ao STF. A primeira ${ }^{41}$, com base nas gravações do empresário Joesley Batista, teve seu seguimento negado pela Câmara dos Deputados em 02 de agosto de 2017, por 263 votos contra o processamento da denúncia e 227 a favor; a segunda ${ }^{42}$, que cuidava de obstrução à justiça e formação de quadrilha, estava, ao tempo da aprovação da reforma eleitoral, para manifestação da Câmara dos Deputados, arquivada posteriormente (25.10.2017), por 251 votos contra a admissibilidade e 233 a favor.

Nesse quadro, o sentimento da antipolítica apontava para uma reforma política. Sob este título, no entanto, aprovaram-se medidas legislativas que levam ao caminho oposto - a manutenção do statu quo.

\subsubsection{Contexto legislativo}

No prazo final para vigência das eleições de 2018, conquanto sob um longo período de debates - restritos ao Parlamento - foi aprovada uma série de mudanças legislativas, entre as quais a Emenda Constitucional n 97, de 4 de outubro de 2017, que estabeleceu “[...] normas de acesso dos partidos políticos aos recursos do fundo partidário e ao tempo de propaganda gratuita no rádio e televisão" - segundo revela a ementa ${ }^{43}$.

Com a nova redação do $\S 3^{\circ}$ do artigo 17 da Constituição Federal concedida pela EC no 97/2017 ${ }^{44}$, somente terão direito a recursos do fundo partidário e acesso gratuito ao rádio e à televisão os partidos que, alternativamente: a) obtiverem nas eleições para Câmara dos Deputados, no mínimo, 3\% (três por cento) dos votos válidos,

\footnotetext{
${ }^{40}$ Confira o levantamento completo em: <http://www.dw.com/pt-br/quantos-parlamentares-são-alvo-de-processos-no-supremo/a-38467849>. Acesso em: 6 nov. 2017.

${ }^{41}$ Observe a primeira denúncia em: <http://www2.camara.leg.br/camaranoticias/noticias/POLITICA/ 538514-CAMARA-NEGA-AUTORIZACAO-PARA-PROCESSO-CONTRA-TEMER-NO-SUPREMO.html>. Acesso em: 6 nov.2017.

${ }^{42}$ Veja a segunda denuncia em: <http://www2.camara.leg.br/camaranoticias/noticias/POLITICA/547188-CAMARA-NAO-AUTORIZA-PROCESSO-POR-ORGANIZACAO-CRIMINOSA-CONTRA-TEMER-E-DOIS-MINISTROS. html>. Acesso em: 6 nov.2017.

${ }^{43}$ Ementa da EC n 97/2017: “Altera a Constituição Federal para vedar as coligações partidárias nas eleições proporcionais, estabelecer normas sobre acesso dos partidos políticos aos recursos do fundo partidário e ao tempo da propaganda gratuito no rádio e na televisão e dispor sobre regras de transição." Disponível em: <http://www.planalto.gov.br/ccivil_03/constituicao/emendas/emc/emc97.htm>. Acesso em:03 nov. 2017.

${ }^{44} \S 3^{\circ}$ Somente terão direito a recursos do fundo partidário e acesso gratuito ao rádio e à televisão, na forma da lei, os partidos políticos que alternativamente:

I - obtiverem, nas eleições para a Câmara dos Deputados, no mínimo, 3\% (três por cento) dos votos válidos, distribuídos em pelo menos um terço das unidades da Federação, com um mínimo de $2 \%$ (dois por cento) dos votos válidos em cada uma delas; ou

II - tiverem elegido pelo menos quinze Deputados Federais distribuídos em pelo menos um terço das unidades da Federação.
} 
distribuídos em pelo menos um terço das unidades da Federação, com um mínimo de $2 \%$ (dois por cento) dos votos válidos de cada uma delas; ou b) tiverem elegidos 15 deputados federais distribuídos em um terço da Federação.

A barreira eleitoral, no entanto, só entrará em vigor, integralmente, em 2030, aplicando-se as regras de transição previstas nos incisos I, II e III do artigo $3^{\circ}$ da EC no $97 / 2017^{45}$, às eleições anteriores, desde a legislatura seguinte à de 2018 , até a de 2026 .

Na eleição seguinte à de 2018, serão exigidos dos partidos políticos 1,5\% de votos obtidos para deputados federais, distribuídos em um terço dos Estados, com o mínimo de $1 \%$ de votos por unidade da Federação, ou, nove deputados federais eleitos em pelo menos um terço dos Estados. Nas eleições posteriores à de 2022, o mínimo de $2 \%$ dos votos recebidos para deputado federal, também em um terço dos Estados, com pelo menos $1 \%$ dos votos de cada Estado, ou 11 deputados federais eleitos distribuídos em um terço das U.F. Nas eleições seguintes à de 2026, o mínimo de votos exigidos será de 2,5\% também em um terço dos Estados, com pelo menos 1,5\% de votos válidos, ou, alternativamente, 13 deputados federais eleitos em um terço da Federação.

Sem o preenchimento dos requisitos legais, os partidos perdem o acesso ao fundo partidário e ao horário gratuito eleitoral, não havendo, no entanto, impedimento ao exercício do mandato dos deputados eleitos, que poderiam, facultativamente, optar por uma nova filiação ( $§ 5^{\circ}$ do art. 17 da CF).

Algumas modificações legislativas, aprovadas concomitantemente à nova cláusula de barreira, agravam a situação dos pequenos partidos. Vão além da similaridade da restrição ao acesso ao fundo partidário e ao horário gratuito de rádio e televisão,

\footnotetext{
${ }^{45} \mathrm{O}$ disposto no $\S 3^{\circ}$ do art. 17 da Constituição Federal quanto ao acesso dos partidos políticos aos recursos do fundo partidário e à propaganda gratuita no rádio e na televisão aplicar-se-á a partir das eleições de 2030. Parágrafo único. Terão acesso aos recursos do fundo partidário e à propaganda gratuita no rádio e na televisão os partidos políticos que:

I - na legislatura seguinte às eleições de 2018:

a) obtiverem, nas eleições para a Câmara dos Deputados, no mínimo, 1,5\% (um e meio por cento) dos votos válidos, distribuídos em pelo menos um terço das unidades da Federação, com um mínimo de 1\% (um por cento) dos votos válidos em cada uma delas; ou

b) tiverem elegido pelo menos nove Deputados Federais distribuídos em pelo menos um terço das unidades da Federação;

II - na legislatura seguinte às eleições de 2022:

a) obtiverem, nas eleições para a Câmara dos Deputados, no mínimo, 2\% (dois por cento) dos votos válidos, distribuídos em pelo menos um terço das unidades da Federação, com um mínimo de 1\% (um por cento) dos votos válidos em cada uma delas; ou

b) tiverem elegido pelo menos onze Deputados Federais distribuídos em pelo menos um terço das unidades da Federação;

III - na legislatura seguinte às eleições de 2026:

a) obtiverem, nas eleições para a Câmara dos Deputados, no mínimo, 2,5\% (dois e meio por cento) dos votos válidos, distribuídos em pelo menos um terço das unidades da Federação, com um mínimo de 1,5\% (um e meio por cento) dos votos válidos em cada uma delas; ou

b) tiverem elegido pelo menos treze Deputados Federais distribuídos em pelo menos um terço das unidades da Federação.
} 
conforme estava contido na cláusula de barreira prevista na Lei n 9.096/95, julgada inconstitucional pelo STF.

A primeira está prevista na própria EC n 97/97, qual seja, o fim das coligações proporcionais, pois a partir das eleições de 2020, não serão mais permitidas coligações proporcionais.

As coligações partidárias no sistema proporcional são importantes para as pequenas agremiações partidárias que necessitam se unirem a outros partidos, muitas vezes, com o mesmo viés ideológico, no acesso ao Parlamento. Atendem as minorias do sistema pluripartidário brasileiro, prestigiado constitucionalmente.

O fim das coligações proporcionais dificulta a unidade dos pequenos partidos em coligações e, beneficia, assim como a própria cláusula de barreira, os partidos políticos tradicionais, que contam com grande estrutura de poder, constituindo um duplo obstáculo às minorias, muitas vezes mais ideologizadas do que as grandes agremiações, não raro acusadas de fisiologismo.

A segunda intervenção legislativa advém da impossibilidade do acesso ao fundo partidário no ano eleitoral. Com o fim do financiamento de campanha eleitoral por pessoas jurídicas, em decorrência do julgamento da ADI n 4560/DF, e a experiência diminuta das doações de pessoas físicas no último pleito (2016), o financiamento público tornou-se a maior fonte de custeio das despesas eleitorais dos partidos, suportadas, tanto pelo Fundo Especial de Financiamento de Campanha ${ }^{46}$, recém-criado pela Lei no 13.478/2017, quanto pelo Fundo Partidário previsto na Lei no 9.096/95, que expressamente permite sua utilização para despesas dos pleitos eleitorais (art. 44, III da Lei no $9.096 / 96)^{47}$.

O Fundo Partidário aprovado no orçamento para 2018 se aproxima aos $900 \mathrm{mi}$ Ihões ${ }^{48}$. Sem esses valores, as minorias partidárias teriam suas chances eleitorais reduzidas contra os demais partidos, que contam com acesso aos dois fundos de financiamento de campanhas eleitorais.

A terceira e última mudança legislativa, influente nos efeitos das cláusulas de barreiras, refere-se aos programas partidários gratuitos na televisão - os exibidos fora do período de propaganda eleitoral - que foram extintos em $1^{\circ}$ de janeiro de 2018 (art.

\footnotetext{
${ }^{46}$ Art. 16-C. O Fundo Especial de Financiamento de Campanha (FEFC) é constituído por dotações orçamentárias da União em ano eleitoral, em valor ao menos equivalente: (Incluído pela Lei no 13.487, de 2017).

I - ao definido pelo Tribunal Superior Eleitoral, a cada eleição, com base nos parâmetros definidos em lei; (Incluído pela Lei $\mathrm{n}^{\circ} 13.487$, de 2017).

II - a $30 \%$ (trinta por cento) dos recursos da reserva específica de que trata o inciso II do § 30 do art. 12 da Lei no 13.473, de 8 de agosto de 2017. (Incluído pela Lei n 13.487, de 2017).

${ }^{47}$ Art. 44. Os recursos oriundos do Fundo Partidário serão aplicados:

III - no alistamento e campanhas eleitorais;

${ }^{48}$ Sobre os valores do fundo partidário para 2018, consultar: <http://g1.globo.com/jornal-nacional/noticia/2017/09/governo-reserva-quase-r-900-milhoes-para-fundo-partidario.html>. Acesso em: 6 nov..2017.
} 
$5^{\circ}$ da lei no $\left.13.487 / 2017\right)^{49}$, restando, agora, exclusivamente, a propaganda eleitoral gratuita, com início em 15 de agosto de cada ano eleitoral.

A vedação ao acesso gratuito ao rádio e à televisão excluirá os partidos minoritários dessa exposição à mídia (televisão e rádio), justamente durante o período eleitoral, beneficiando diretamente os grandes partidos, que antes já gozam do privilégio de tempo diferenciado e proporcional às bancadas na Câmara dos Deputados.

O fim das coligações proporcionais, a impossibilidade do uso do fundo partidário no ano eleitoral e a extinção do programa partidário, concomitante à vedação ao acesso do direito de antena, constituem restrições legislativas que acentuam a severidade da cláusula de barreira imposta pela Emenda Constitucional n 97/2017, se comparada com a Lei no 9096/95, declarada, como já registrado, inconstitucional no julgamento das ADIs no 1.351/DF e n. 1.354/DF.

\subsubsection{Do contexto partidário}

No julgamento das ADIs no 1.351/DF e no 1.354/DF, em dezembro de 2006, o min. relator Marco Aurélio ${ }^{50}$ (STF, 2007, p. 33) fez consignar em seu voto que "São vinte e nove os partidos registrados no Tribunal Superior Eleitoral", nominando cada um deles.

Hoje, segundo dados do TSE ${ }^{51}$, são 35 partidos políticos registrados. Foram acrescidos: PSD - Partido Social-Democrata (27.09.2011); PPL - Partido da Pátria Livre (04.10.2011); PEN - Partido Ecológico Nacional (19.06.2012); PROS - Partido Republicano da Ordem Social (24.09.2013); SD - Solidariedade (24.09.2013); NOVO - Partido Novo (15.09.2015); REDE - Rede Sustentabilidade (22.09.2015) e, PMB - Partido da Mulher Brasileira (29.09.2015).

Verifica-se que o número atual de partidos políticos não difere substancialmente do encontrado pelo TSE no julgamento das ADIs n 1.351/DF e n 1.354/DF, capaz de justificar um novo entendimento jurídico por esta razão.

O aumento averiguado decorre, em parte, da intervenção do TSE editada na Resolução n॰ 22.610, de 27 de outubro de $2007^{52}$, que considerou justa causa para desfiliação, a criação de um partido, não incorrendo em perda de mandato aquele que migrasse para uma nova legenda. Nota-se que todos os novos partidos foram criados

\footnotetext{
${ }^{49}$ Art. $5^{\circ}$ Ficam revogados, a partir do dia $1^{\circ}$ de janeiro subsequente à publicação desta Lei, os arts. 45, 46, 47, 48 e 49 e o parágrafo único do art. 52 da Lei n 9.096, de 19 de setembro de 1995.

${ }^{50}$ BRASIL, Supremo Tribunal Federal. Acórdão no 1.351/2007. Disponível em: <http://redir.stf.jus.br/paginadorpub/paginador.jsp?docTP=AC\&docID=416150>. Acesso em: 30 nov. 2017. p. 33.

${ }^{51}$ Partidos registrados no TSE. Disponível em: <http://www.tse.jus.br/partidos/partidos-politicos/registrados-no-tse>. Acesso em: 3 nov. 2017.

${ }^{52}$ Resolução no 22.610/2007 do TSE. Disponível em: <http://www.tse.jus.br/legislacao/codigo-eleitoral/normas-editadas-pelo-tse/resolucao-nb0-22.610-de-25-de-outubro-de-2007-brasilia-2013-df >. Acesso em: 3 nov. 2017.
} 
após a Resolução n 22.610/2007, e sempre no ano anterior aos pleitos eleitorais, atendendo ao princípio da anterioridade eleitoral ${ }^{53}$.

Os novos partidos contaram com a preferência da filiação dos depositários de mandatos insatisfeitos com seus partidos, que, de tal modo, se protegiam com a excludente de infidelidade partidária - mudança para um novo partido - fugindo da decretação judicial da perda de mandato eletivo. Gerou-se, com efeito, um círculo vicioso a cada eleição.

A aplicação do patamar eleitoral previsto na Lei no 9.069/95 restringiria o funcionamento de 22 partidos, tomando-se por base a eleição geral anterior ao julgamento do STF (2006). O min. Marco Aurélio de Mello ${ }^{54}$ consignou em seu voto:

[...] dos vinte e nove partidos existentes, apenas sete alcançaram e suplantaram o patamar de cinco por cento dos votos para a Câmara dos Deputados em todo o território nacional, distribuídos de tal forma a perfazer pelo menos dois por cento em cada Estado.

Utilizando os dados estatísticos das eleições gerais no Brasil de 2014, fornecidos pelo $\mathrm{TSE}^{55}$, sobre os números totalizados para deputado federal em todo Brasil, simulou-se a aplicação das regras atuais da cláusula de barreira inserida pela EC n 97/2017 - 3\% dos votos, distribuídos em 9 Estados, com o mínimo de 2\% em cada U.F., ou 15 deputados federais distribuídos em um terço da Federação.

Segundo a simulação, teriam acesso ao fundo partidário e ao horário eleitoral gratuito os partidos: PT - Partido dos Trabalhadores (13,9\%); PSDB - Partido da Social Democracia Brasileira (11,37\%); PMDB - Partido do Movimento Democrático Brasileiro (11,08\%); PP - Partido Popular (6,60\%); PSB - Partidos Socialista Brasileiro (6,44\%); PSD - Partido Social Democrata (6,13\%); PR - Partido da República (5,79\%); PRB - Partido Republicano Brasileiro (4,54\%); DEM - Democratas (4,20\%); PTB - Partido Trabalhista Brasileiro (4,02\%); PDT - Partido Democrático Trabalhista (3,62\%) e SD - Solidariedade $(2,76 \%)$, que apesar de não atingir o percentual geral exigido, alternativamente, conta com 15 deputados federais eleitos em 14 Estados.

A cláusula de barreira excluiria do fundo partidário e da propaganda gratuita no rádio e televisão (20) vinte partidos políticos e 19,5\% do eleitorado votante restaria sem representação na Câmara dos Deputados.

\footnotetext{
${ }^{53} \mathrm{CF}$ - Art. 16. A lei que alterar o processo eleitoral entrará em vigor na data de sua publicação, não se aplicando à eleição que ocorra até um ano da data de sua vigência. (Redação dada pela Emenda Constitucional n 4 , de 1993). Acesso em: 3 nov. 2017.

${ }^{54}$ BRASIL, Supremo Tribunal Federal. Acórdão no 1.351/2007. Disponível em: <http://redir.stf.jus.br/paginadorpub/paginador.jsp?docTP=AC\&docID=416150>. Acesso em: 30 nov. 2017. p. 15.

${ }^{55}$ BRASIL, Tribunal Superior Eleitoral. Estatística das eleições 2014 - Deputado Federal. Disponível em: <http://www.tse.jus.br/eleitor-e-eleicoes/estatisticas/eleicoes/eleicoes-anteriores/estatisticas-candidaturas-2014/estatisticas-eleitorais-2014-resultados>. Acesso em: 30 out. 2017.
} 
Da comparação entre a aplicação prática das duas cláusulas de desempenho partidário, extrai-se a conclusão de que somente sete partidos políticos suplantariam as exigências de 2006 e 2014. São eles: PT - Partido dos Trabalhadores; PSDB - Partido da Social Democracia Brasileira; PMDB - Partido do Movimento Democrático Brasileiro; PP - Partido Popular; PSB - Partidos Socialista Brasileiro; DEM (PFL) - Democratas; PDT - Partido Democrático Trabalhista.

Com o resultado da recente eleição geral de 2018 e o início da aplicação (parcial) da cláusula de barreira, que se dará entre os exercícios de 2019 até 2023, segundo a previsão do $\S 3^{\circ}$ do art. 17 da Constituição Federal, alterada pela EC n 97/2017 ${ }^{56}$, dentre as 35 agremiações partidárias, 14 não mais terão acesso ao fundo partidário e ao direito de antena, excluindo-se, consequentemente, do benefício estatal os seguintes partidos: Rede Sustentabilidade, Patriota, PHS, DC, PCdoB, PCB, PCO, PMB, PMN, PPL, PRP, PRTB, PSTU, PTC. ${ }^{57}$

O contexto político, legislativo e partidário da implantação, por adição constitucional, da nova cláusula de desempenho eleitoral, revela um aspecto conflituoso da luta pela perpetuação do poder, na expressão de Luís Felipe Miguel ${ }^{58: "[. . .] ~ a ~ c o m p e t i c ̧ a ̃ o ~}$ entre elite", na busca pelo direito de representação social, excluindo as minorias partidárias dos meios igualitários do acesso político. Cumpre, no entanto, confrontar esse adendo com o arcabouço normativo principiológico da democracia brasileira fixado pelo constituinte originário.

\subsection{Democracia brasileira: pluralismo político, pluripartidarismo e igualdade de chances}

O Brasil adota explicitamente o pluralismo político como um dos fundamentos do Estado Democrático de Direito. Uma sociedade é pluralista quando possibilita a coexistência de núcleos de poder diversificados. Quanto maior a diversidade, maior a representatividade. Interesses conflitantes têm a função de controlar o poder de quem domina o Estado. A liberdade de expressão, a participação política e a tolerância social são essenciais à convivência democrática entre atores e instituições políticas.

\footnotetext{
${ }^{56}$ Art. 17, § 30, I da Constituição Federal:

I- na legislatura seguinte às eleições de 2018:

a) obtiverem, nas eleições para a Câmara dos Deputados, no mínimo, 1,5\% (um e meio por cento) dos votos válidos, distribuídos em pelo menos um terço das unidades da Federação, com um mínimo de $1 \%$ (um por cento) dos votos válidos em cada uma delas; ou

b) tiverem elegido pelo menos nove Deputados Federais distribuídos em pelo menos um terço das unidades da Federação;

57 SOUZA, Murilo. Câmara Notícias. 14 partidos não alcançam cláusula de desempenho e perderão recursos, disponível em: <http://www2.camara.leg.br/camaranoticias/noticias/POLITICA/564071-14-PARTIDOS-NAO-ALCANCAM-CLAUSULA-DE-DESEMPENHO-E-PERDERAO-RECURSOS.html>. Acesso em: 10 out. 2018

${ }^{58}$ MIGUEL, Luís Felipe. Democracia e Representação: territórios em disputa. São Paulo: Unesp, 2014, p. 307.
} 
Villas Boas ${ }^{59}$ realça essa opção constitucional brasileira pelo pluralismo partidário com respeito às minorias como "[...] a essência do regime político adotado no Brasil. Não há que se falar em democracia com o sacrifício da minoria maioria."

Acentuando a pluralidade de ideias no sistema político, foi que a Constituição estabeleceu o pluripartidarismo como essência do sistema político nacional (art. 17, caput da CF) identificados, na expressão de Dalmo de Abreu Dallari60: “[...] pela existência de vários partidos igualmente dotados da possibilidade de predominar sobre os demais."

A pluralidade política e partidária, explicitamente exigida no Estado Democrático de Direito, traz a igualdade ao cerne da controversa constitucionalidade das cláusulas de desempenho, de tal maneira que se pode indagar: é possível essa convivência respeitando o direito das minorias?

Há quem a defenda como aprimoramento democrático. Giovanni Sartori advertia dos extremos dos sistemas partidários, especialmente para o pluralismo exacerbado, que considerava muito pouco estudado. Chegou a atribuir um sistema de contagem, que seria o número ideal de agremiações partidárias que estimava entre cinco e seis. Pondera o cientista político italiano:

"[...] É conveniente repetir que os partidos em questão devam ser relevantes, isto é, aqueles que permanecem após a exclusão de partidos aos quais falta o 'potencial para coalização', a menos que seu 'poder de intimidação' influa na tática de competição interpartidária" ${ }^{\prime \prime 1}$

A objeção é a de que a proliferação de partidos, própria da representação proporcional, fragmentaria a representatividade política, tornando a governabilidade dificultada, impossibilitando decisões rápidas e efetivas. Para José Antônio Giusti Tavares $^{62}$, a adoção das limitações de desempenho "[...] asseguraria mais vigor e efetividade à representação proporcional".

José Afonso da Silva ${ }^{63}$ considera possível, no âmbito constitucional brasileiro, que a legislação infraconstitucional possa prever o "[...] controle quantitativo dos partidos", quando menciona o funcionamento parlamentar de acordo com a lei. O constitucionalista mineiro destaca que esse "[...] controle quantitativo se realiza pela instituição

${ }^{59}$ VILLAS BOAS, Marco Anthony Steverson. A Cláusula de Barreira no Direito Brasileiro. Revista do Instituto do Direito Brasileiro, ano 2, n. 8, 2013. Disponível em: <http://www.cidp.pt/publicacoes/revistas/ridb/2013/08/2 013_08_08891_08980.pdf>. Acesso em: 05 nov. 2017.

${ }^{60}$ DALLARI, Dalmo de Abreu. Elementos da Teoria Geral do Estado. 18: ed. São Paulo: Saraiva, 1994, p. 140.

${ }^{61}$ SARTORI, Gionanni. Partidos políticos e sistemas partidários. Tradução de Waltensir Dutra. Rio de Janeiro: Zahar; Brasília: Universidade de Brasília, 1982, p. 156-157

${ }^{62}$ TAVARES, José Antônio Giusti. Sistemas eleitorais nas democracias contemporâneas: teorias, instituições e estratégia. Rio de Janeiro: Relume-Dumará, 1994, p. 46.

${ }^{63}$ SILVA, José Afonso da. Curso de Direito Constitucional Positivo. 32. ed. São Paulo: Malheiros, 2009, p. 407. 
de mecanismos normativos que limitam as possibilidades de ampliação, ad libitum, dos partidos políticos".

A crítica nacional é pragmática e incide, principalmente, sobre as siglas de aluguel - pequenos partidos que nas eleições negociam seus tempos de propaganda gratuita no rádio e televisão. Seriam identificados com seus proprietários e não pelo conteúdo programático e se beneficiariam do fundo partidário, além da propaganda nos meios de comunicação massivos custeados pelo erário. Este seria mais um fator estimulante da proliferação dos partidos.

Marco Aurélio de Mello ${ }^{64}$, em seu voto na ADIs no 1.351/DF, repudia essa prenoção: "Esta Corte é chamada a pronunciar-se sobre a matéria a partir da Constituição Federal. Descabe empunhar a bandeira leiga da condenação dos partidos de aluguel".

Não parece próprio do sistema democrático, que elege o pluralismo político como fundamento constitucional, estagnar o processo social de renovação de ideias e lideranças, seja vedando a representação política das minorias no Parlamento, ou asfixiando o funcionamento das legendas partidárias. O direito de oposição deve ser incentivado como necessário ao controle da situação. Assevera Eneida Desiree Salgado65:

A exclusão, direta ou postergada, como uma lenta exterminação, dos partidos políticos menos expressivos, contraria frontalmente o sistema proporcional, a representação das minorias e o princípio da democracia deliberativa. Não há igual consideração e respeito quando, abaixo de um patamar de votos determinados, os partidos e os mandatários passam a ser tratados como de segunda categoria.

Paulo Bonavides ${ }^{66}$ nomina fortemente as medidas excludentes da representação política de "[...] assassínio eleitoral ou golpe de Estado pelas urnas", arrematando que "[...] far-se-á assim da representação proporcional o privilégio irremediável das organizações partidárias mais fortes e em melhor harmonia com os interesses da ordem estabelecida".

Havendo a impossibilidade de sobrevivência legal e igualitária das minorias pela proibição de acesso aos meios e recursos institucionais para o pleno exercício dos direitos políticos de oposição - "a democracia não tem um futuro democrático e deixa de ser uma democracia no nascedouro", uma vez que "o futuro democrático de uma democracia depende da convertibilidade das maiorias em minorias e, inversamente, das minorias em maiorias". 67

\footnotetext{
${ }^{64}$ BRASIL, Supremo Tribunal Federal. Acórdão no 1.351/2007. Disponível em: <http://redir.stf.jus.br/paginadorpub/paginador.jsp?docTP=AC\&docID=416150>. Acesso em: 30 nov. 2017.

${ }^{65}$ SALGADO, Eneida Desiree. Princípios constitucionais eleitorais. 2. ed. Belo Horizonte: Fórum, 2015, p. 187.

${ }^{66}$ BONAVIDES, Paulo. Ciência Política. 10. ed. São Paulo: Malheiros, 2000, p. 330.

${ }^{67}$ SARTORI, Giovanni. A teoria da democracia revisitada: o debate contemporâneo. V. 1. São Paulo: Ática, 1994 , p. 45.
} 
A Constituição de Portugal de 1974 achou por bem positivar a vedação à cláusula de barreira no artigo 152, dispondo que "A lei não pode estabelecer limites à conversão dos votos em mandatos por uma exigência de uma percentagem de votos nacional mínima" ${ }^{\prime \prime}$. A Constituição brasileira de 1988 a fez mediante a positivação dos princípios do pluralismo político, do pluripartidarismo e da igualdade de chances no sistema proporcional.

As restrições de desempenho criadas pela Emenda Constitucional no 97/2017, apesar de não impedir, diretamente, a ascensão ao mandato do candidato do partido que não atendeu aos requisitos percentuais, nesse caso preservada, proíbe o acesso ao fundo partidário e o direito de antena, violando a igualdade entre os partidos, denominada igualdade de chances. Canotilho ${ }^{69}$, a esse respeito, acentua: "O princípio do voto igual, na sua dimensão de igual valor quanto ao resultado, tem sido estendido à própria luta eleitoral".

Em seu voto na ADI n 1.351/DF, o min. Gilmar Mendes ${ }^{70}$ ressalta o princípio da igualdade de chances:

O Princípio da igualdade entre os partidos políticos é fundamental para a adequada atuação dessas instituições no complexo processo democrático. Impõe-se por isso, uma neutralidade do Estado em face das instituições partidárias, exigência que se revela tão importante quanto difícil de ser implementada. [...] Daí afirmar Dieter Grimm que a neutralidade estatal deve ser entendida como não-influência da desigualdade, o que Ihe confere caráter de igualdade formal.

A posição do min. Gilmar Mendes, elaborada com base na teoria constitucional alemã, mostra-se intermediária aos argumentos até agora apresentados. Considera "[...] possível, sim, ao legislador pátrio, o estabelecimento de uma cláusula de barreira ou de desempenho que impeça a atribuição de mandatos à agremiação que não obtiver um dado percentual de votos"71, como a Alemanha, e rebela-se contra a desigualdade de concorrência, com a restrição ao fundo partidário e ao direito de antena. Prosseguindo em seu voto, o ministro pondera:

Como se vê, trata-se de uma restrição absoluta ao próprio funcionamento parlamentar do partido, sem qualquer repercussão sobre os mandatos de seus representantes. Não

\footnotetext{
${ }^{68}$ PORTUGAL. Constituição da República de Portugal. Disponível em: <https://www.parlamento.pt/Legislacao/Paginas/ConstituicaoRepublicaPortuguesa.aspx>. Acesso em: 9 nov. 2017.

${ }^{69}$ CANOTILHO, J. J. Gomes. Direito Constitucional e teoria da Constituição. 7. ed. Coimbra: Almedina, 2003, p. 305.

${ }^{70}$ MENDES, Gilmar. STF. Voto na ADI no 1.531/DF - 2007. Disponível em: <http://www.stf.jus.br/imprensa/pdf/ VotoGilmarADI1351.pdf>. Acesso em: 7 nov.2017, p. 19.

${ }^{71}$ MENDES, Gilmar. STF. Voto na ADI no 1.531/DF - 2007. Disponível em: <http://www.stf.jus.br/imprensa/pdf/ VotoGilmarADI1351.pdf>. Acesso em: 7 nov. 2017, p. 17.
} 
se estabelece qualquer tipo de mitigação, mas simplesmente veda-se o funcionamento parlamentar ao partido, com as consequências que isso pode gerar, como o não-recebimento dos recursos provenientes do fundo partidário, ou o seu recebimento em percentuais ínfimos, e a vedação do acesso ao rádio e à televisão. ${ }^{72}$

A cláusula de desempenho abordada pelo min. Gilmar Mendes na ADI n. 1.531/ DF, originária da Lei n 9.096/95, é similar à prevista na EC n 97/2017, e bloqueia o acesso dos partidos políticos ao direito de antena - hoje restrito à propaganda eleitoral gratuita - e ao Fundo Partidário - financiamento de campanha essencial em períodos eleitorais, afrontando, pois, como já decidiu o STF, a própria subsistência partidária e o princípio da igualdade de chances.

O questionamento que se faz é se as novas circunstâncias da aprovação da EC n॰ 97/2017 - o contexto político, legislativo e partidário - antes abordadas neste artigo, seriam capazes de alterar o precedente judicial que se fez unânime no STF, o qual considerou inconstitucional a cláusula de barreira na Lei no 9.096/95, na medida em que as restrições são as mesmas e atingem diretamente o funcionamento partidário.

Defende-se a tese de que não. E a razão disso é que as garantias constitucionais atuantes são as mesmas positivadas - pluralismo, pluripartidarismo e igualdade - originalmente na Carta Política de 1988. Não há, portanto, qualquer fundamento aditado que motive outra visão. As anomalias dos sistemas, inclusive as percepções leigas citadas pelo min. Marco Aurélio de Mello, sucumbem à representação proporcional, que demanda sempre maior inclusão social. A lição de Robert Dahl ${ }^{73}$ é receptível: "That the better procedure should be preferred to the worse holds even if all the procedures proposed are in some respects defective, as might often be the case".

Não se deve perder de vista a noção de que o sistema eleitoral brasileiro já conta com uma cláusula de barreira efetiva: o coeficiente eleitoral ${ }^{74}$. Constantemente, a sociedade indaga a razão de um candidato a cargo proporcional, que recebeu mais votos do que outros, não ter sido eleito. O ressurgimento legislativo de cláusulas de desempenho tem como escopo evitar o acesso das minorias ao poder, refletindo o distanciamento popular dos representantes e a tentativa de perpetuação das grandes oligarquias partidárias.

Sempre necessário é relembrar o diagnóstico de Fabio Konder Comparato ${ }^{75}$ :

\footnotetext{
${ }^{2}$ MENDES, Gilmar. STF. Voto na ADI no 1.531/DF - 2007. Disponível em: <http://www.stf.jus.br/imprensa/pdf/ VotoGilmarADI1351.pdf>. Acesso em: 7 nov.2017, p. 15.

${ }^{73}$ DAHL, Robert A. Democracy e and its critics. New Haven and London: Yale University Press, 1989, p. 110.

${ }^{74}$ Leciona Djalma Pinto: “Um exemplo de cláusula de barreira pode ser considerado o quociente eleitoral previsto na legislação brasileira. O partido que não atingi-lo, em uma eleição, não poderá indicar nenhum deputado ou vereador no respectivo pleito. Não participa da distribuição das cadeiras". DJALMA, Pinto. Direito Eleitoral: Improbidade administrativa e Responsabilidade Fiscal - noções gerais. São Paulo: Atlas, 2003, p. 163. ${ }^{75}$ COMPARATO, Fábio Konder. Sentido e alcance do processo eleitoral no regime democrático. Revista Estudos Avançados, vol. 38, n. 14, p. 307-320, 2000. Disponível em: <https://www.revistas.usp.br/eav/article/ view/9518/11087>. Acesso em: 9 nov. 2017. p. 315.
} 
O magno problema político brasileiro não é, pois, como pareceu a certos cientistas políticos sempre prontos a assimilar teses e categorias forjadas nas oficinas intelectuais do primeiro mundo, uma crise de governabilidade. O nosso problema é mais profundo e diz respeito, muito além da esfera de governo, ao próprio regime político: é a tentativa absurda de fazer funcionar uma democracia sem povo.

A aproximação dos partidos políticos com o povo e a maior inclusão política das minorias na representação política constituem o objetivo a ser perseguido no ideal democrático.

Para ser preciso, somente haveria uma diferenciação substancial na nova cláusula de barreira, especificamente em relação à fonte normativa: a criação por meio de Emenda Constitucional.

Este obstáculo poderá ser suplantado pelo Supremo Tribunal Federal, em uma provável arguição de constitucionalidade, que, decerto, haverá de ser proposta pelos legitimados, especialmente, os partidos políticos prejudicados, uma vez que já há precedência, da conflituosa possibilidade, da declaração de inconstitucionalidade de emenda constitucional como manifestado na ADI no $1.946 \mathrm{MC}{ }^{76}$

\section{CONCLUSÃO}

O sentimento de crise política na sociedade produz a contraditória reação popular de aversão ao que é político, como algo desprezível, fomentando ainda mais a individualidade social.

Os partidos políticos - canais democráticos de representação popular - são receptores das consequências desse repúdio social, não sem razão, pois, muitas das agremiações políticas, fecharam-se aos interesses de seus representados, transformando-se em instituições oligárquicas.

A democracia, ao contrário dos regimes totalitários, demanda sua constante evolução responsiva aos desafios da sociedade mutável e poderes constituídos, que tendem a se preservar no poder, utilizando-se das prerrogativas ofertadas pela representação que exercem.

Como limitação ao aperfeiçoamento da democracia partidária e a garantias dos direitos das minorias, grande parte dos sistemas democráticos proporcionais ocidentais estabelece restrições aos limites da representação, impondo aos partidos políticos

\footnotetext{
${ }^{76}$ O STF já assentou o entendimento de que é admissível a ação direta de inconstitucionalidade de emenda constitucional, quando se alega, na inicial, que esta contraria princípios imutáveis ou as chamadas cláusulas pétreas da Constituição originária (art. 60, § 4º da CF). Precedente: ADI n 939 (RTJ151/755). [ADI n 1.946 MC, rel. min. Sydney Sanches, j. 29-4-1999, DJ de 14-9-2001.]. Disponível em: <http://redir.stf.jus.br/paginadorpub/ paginador.jsp?docTP=AC\&docID=347341>. Acesso: 9 nov. 2017.
} 
percentuais de desempenho para o acesso ao Parlamento, ou a instrumentos de financiamento da política e promoção partidária nas redes de comunicação social.

No Brasil, foram várias as tentativas históricas de criação de barreiras políticas, tanto antes do restabelecimento do regime democrático iniciado com a Constituição de 1988, quando sob sua égide - até agora nunca implantadas. O Supremo Tribunal Federal, como no caso da ADI n. 1531/DF, que obstaculizou a vigência das cláusulas de barreiras impostas pela Lei dos Partidos Políticos (Lei n 9.096/95), foi o fator impeditivo dessa medida protetiva do poder estabelecido.

Recentemente, sob o título de "Reforma Política", por meio da Emenda Constitucional n 97/2017, foi revitalizada a cláusula de barreira, para impedir os partidos que não conseguirem três por cento dos votos válidos para a Câmara dos Deputados, distribuídos em pelo menos um terço dos Estados, com o mínimo de dois por cento por unidade da Federação, ou, alternativamente, eleitos 15 deputados federais, distribuídos em um terço dos Estados, não tenham acesso ao Fundo Partidário e ao Programa Eleitoral gratuito no Rádio e Televisão. A cláusula que alterou o $§ 3^{\circ}$ do artigo 17 da Constituição Federal entrará em vigor integralmente até as eleições de 2030, sendo efetivada parcialmente a cada eleição.

A cláusula de barreira vigente se torna ainda mais gravosa, pois aplicada conjuntamente a outras alterações normativas, quais sejam, (i) o fim das coligações proporcionais, que dificulta a costumeira união das siglas minoritárias; (ii) a vedação ao programa eleitoral gratuito no rádio e televisão, durante o pleito eleitoral, antes utilizado anualmente, e extinto a partir de 2018, e, por fim, (iii) a impossibilidade de utilização do Fundo Partidário, hoje, importante fonte de financiamento eleitoral, juntamente com o Fundo Especial de Financiamento de Campanha.

A inconstitucionalidade da Emenda Constitucional em questão é flagrante, pois ofende as garantias constitucionais do pluralismo político, do pluripartidarismo e da igualdade de chances que devem ser ensejadas às agremiações partidárias. $\mathrm{O}$ STF, provavelmente, declarará também sua inconstitucionalidade, confirmando o entendimento firmado no julgamento da ADI no. 1.531/DF, em 2006, pois é imperativo hermenêutico clássico de que "onde existe a mesma razão fundamental, prevalece a mesma regra de Direito"77 e, por conseguinte, impõe-se a mesma decisão para o deslinde da questão examinada.

A implantação da EC 97/2017, nas eleições de 2018, mesmo utilizando do menor percentual da transição iniciada, retirará de 14 partidos o fundo partidário e a propaganda gratuita eleitoral a partir de 2019. Foram atingidos vários partidos novos e, também, partidos históricos como é o caso Partido Comunista do Brasil ( PCdoB), fundado desde 1962.

\footnotetext{
${ }^{77}$ FALCÃO, Raimundo Bezerra. Hermenêutica. São Paulo: Malheiros, 2000, p. 262 e MAXIMILIANO, Carlos. Hermenêutica e aplicação do direito. 20. ed. Rio de Janeiro: Forense, 2011, p. 200.
} 
O momento político reclama medidas inclusivas na política, buscando a participação popular efetiva, e não excludentes e protetivas das estruturas oligárquicas partidárias, como as cláusulas de barreira, que visam à exterminação gradativa das minorais, essenciais ao pluralismo democrático. Serve a lição de Comparato78: "A representação popular, em suma, só é legítima quando instituída pelo próprio povo".

Para finalizar, é imperioso destacar que a tese da governabilidade política como fundamento da necessidade de limitação ou restrição da existência das minorias políticas e de seus direitos de participação igualitária nas instituições representativas pode comprometer irremediavelmente um dos valores civilizatórios centrais das democracias constitucionais, qual seja, o princípio de que a democracia é o regime político da "vontade" das maiorias, mas com respeito pleno aos direitos fundamentais das minorias.

\section{REFERÊNCIAS}

ATALIBA, Geraldo. Limites à Revisão Constitucional de 1993. Revista de Informação Legislativa, V. 30, no 120, out./dez, 1993. Disponível em: <http://www2.senado.leg.br/bdsf/bitstream/handle/ id/176159/000482857.pdf?sequence=3>. Acesso em 29 out. 2017.

AZAMBUJA, Darcy. Teoria Geral do Estado. 44. ed. São Paulo: Globo, 2005.

BAUMAN, Zigmunt; BORDONI, Carlo. Estado de crise. Tradução de Renato Aguiar. Rio de Janeiro, Zahar, 2016.

BOBBIO, Norberto. O Futuro da democracia: uma defesa das regras do jogo. Tradução de Marco Aurélio Nogueira. 13. ed. São Paulo/Rio de Janeiro: Paz e Terra, 2015.

BONAVIDES, Paulo. Ciência Política. 10. ed. São Paulo: Malheiros, 2000.

BRASIL, Supremo Tribunal Federal. Acórdão n 1.351/2007. Disponível em: <http://redir.stf.jus. br/paginadorpub/paginador.jsp?docTP=AC\&docID=416150>. Acesso em: 30 nov. 2017.

BRASIL, Supremo Tribunal Federal. Acórdão no 1.946 MC. Disponível em: <http://redir.stf.jus.br/ paginadorpub/paginador.jsp?docTP=AC\&docID=347341>. Acesso em: 09 nov. 2017.

BRASIL, Tribunal Superior Eleitoral. Estatística das eleições 2014 - Deputado Federal. Disponível em: <http://www.tse.jus.br/eleitor-e-eleicoes/estatisticas/eleicoes/eleicoes-anteriores/estatisticas-candidaturas-2014/estatisticas-eleitorais-2014-resultados>. Acesso em: 30 out. 2017.

BRASIL. Constituição da República Federativa do Brasil de 1967. Disponível em: <http://www. planalto.gov.br/ccivil_03/constituicao/constituicao67.htm>. Acesso em: 27 out. 2017.

BRASIL. Constituição Federal de 1988. Disponível em: <http://www.planalto.gov.br/ccivil_03/ constituicao/constituicao.htm>. Acesso em: 28 out. 2017.

${ }^{78}$ COMPARATO, Fábio Konder. Sentido e alcance do processo eleitoral no regime democrático. Revista Estudos Avançados, vol. 38, n. 14, p. 307-320, 2000. Disponível em: <https://www.revistas.usp.br/eav/article/ view/9518/11087>. Acesso em: 9 nov. 2017. p. 317. 
BRASIL. Lei 4.740 de 15 de julho de 1965. Disponível em: <http://www2.camara.leg.br/legin/ fed/lei/1960-1969/lei-4740-15-julho-1965-368290-publicacaooriginal-1-pl.html>. Acesso em: 26 out. 2017.

BRASIL. Lei no 13.478 de 4 de outubro de 2017. Disponível em: <http://www.planalto.gov.br/ ccivil_03/_ato2015-2018/2017/lei/L13487.htm>. Acesso em: 10 nov. 2017.

BRASIL. Lei no 8.713 de 1993. Disponível em: <http://www.planalto.gov.br/ccivil_03/leis/l8713. htm>. Acesso em: 30 out. 2017.

BRASIL. Lei no 9.096/95. Disponível em: <http://www.planalto.gov.br/ccivil_03/leis/L9096.htm>. Acesso em: 30 out. 2017.

BRASIL. Supremo Tribunal Federal. Acordão n 966/DF. Disponível em: <http://redir.stf.jus.br/paginadorpub/paginador.jsp?docTP=AC\&doclD=266603>. Acesso em: 30 out. 2017.

BUNDESVERFASSUNGSGERICHT. Five per cent barrier clause in the law governing the European elections held unconstitutional. Disponível em: <https://www.bundesverfassungsgericht.de/ SharedDocs/Pressemitteilungen/EN/2011/bvg11-070.html>. Acesso em: 08 fev. 2018.

CAETANO, Marcello. Manual de Ciência Política e Direito constitucional. 6. ed., rev. e ampl. Lisboa: Almedina, 2009. t. I.

CANOTILHO, J. J. Gomes. Direito Constitucional e teoria da constituição. 7. ed. Coimbra: Almedina, 2003.

COMPARATO, Fábio Konder. Sentido e alcance do processo eleitoral no regime democrático. Revista Estudos Avançados, vol. 38, n. 14, p. 307-320, 2000. Disponível em: <https://www.revistas. usp.br/eav/article/view/9518/11087>. Acesso em: 9 nov. 2017.

DAHL, Robert A. Democracy e and its critics. New Haven and London: Yale University Press, 1989.

DALLARI, Dalmo de Abreu. Elementos da Teoria Geral do Estado. 18. ed. São Paulo: Saraiva, 1994.

DJALMA, Pinto. Direito Eleitoral: Improbidade administrativa e Responsabilidade Fiscal - noções gerais. São Paulo: Atlas, 2003.

FALCÃO, Raimundo Bezerra. Hermenêutica. São Paulo: Malheiros, 2000.

FERRAJOLI, Luigi. Poderes selvagens: A crise da democracia italiana. Tradução de Alexandre Araújo de Sousa. São Paulo: Saraiva. 2014.

FRANCO, Afonso Arinos de Melo. História e teoria dos partidos políticos no Brasil. 3. ed. São Paulo: Alfa-Ômega,1980.

HOBBES, Thomas. Leviatã, ou, a matéria, forma e poder de um Estado eclesiástico e civil. Tradução de Rosina D’Angina. 3. ed. São Paulo: Ícone, 2008. 
KELSEN, Hans. A democracia. Tradução de Ivone Castilho Benedetti, Jeferson Luís Camargo, Marcelo Brandão Cipolla e Vera Barkow. 2. ed. São Paulo: Martins Fontes, 2000.

LAMARÃO, Sérgio. Partidos políticos (Extinção). Disponível em: <http://www.fgv.br/cpdoc/ acervo/dicionarios/verbete-tematico/partidos-politicos-extincao>. Acesso em: 26 out. 2017.

MAXIMILIANO, Carlos. Hermenêutica e aplicação do direito. 20. ed. Rio de Janeiro: Forense, 2011.

MENDES, Gilmar. STF. Voto na ADI no 1.531/DF - 2007. Disponível em: <http://www.stf.jus.br/ imprensa/pdf/VotoGilmarADI1351.pdf>. Acesso em: 7 nov.2017.

MICHELS, Robert. A Sociologia dos partidos políticos. Tradução de Arthur Chaudon Brasília: UNB, 1982.

MIGUEL, Luís Felipe. Democracia e representação: territórios em disputa. São Paulo: Unesp, 2014.

PONTES, Roberto Carlos Martins; HOLTHE, Leo Oliveira Van. O Sistema Eleitoral Alemão pós a Reforma de 2013 e a viabilidade de sua adoção no Brasil. Consultoria Legislativa, abril/2015. Disponível em: <http://www2.camara.leg.br/a-camara/documentos-e-pesquisa/estudosnotas-tecnicas/areas-da-conle/tema6/2015_1531-sistema-eleitoral-alemaoleo-van-holthe-e-roberto-pontes>. Acesso em: 26 out. 2017.

PORTUGAL. Constituição da República de Portugal. Disponível em: <https://www.parlamento. pt/Legislacao/Paginas/ConstituicaoRepublicaPortuguesa.aspx>. Acesso em: 9 nov. 2017.

RENNÓ, Lucio R.; SMITH, Amy E.; LAYTON, Matthew L.; PEREIRA, Frederico Batista. Legitimidade e qualidade da democracia no Brasil: uma visão da cidadania. São Paulo: Intermeios; Nashville: LAPOP, 2011.

RODRIGUES, Ricardo. Barreira legal nos sistemas eleitorais proporcionais. Revista de Informação Legislativa. V. 32, n. 126, p. 47-55, abr./jun.1995. Disponível em: <http://www2.senado.leg.br/ bdsf/item/id/176321>. Acesso em: 28 out. 2017.

SALGADO, Eneida Desiree. Princípios constitucionais eleitorais. 2. ed. Belo Horizonte: Fórum, 2015.

SARTORI, Giovanni. A teoria da democracia revisitada: o debate contemporâneo. V. 1. São Paulo: Ática, 1994.

SARTORI, Giovanni. Partidos políticos e sistemas partidários. Tradução de Waltensir Dutra. Rio de Janeiro: Zahar; Brasília: Universidade de Brasília, 1982.

SILVA, José Afonso da. Curso de Direito Constitucional Positivo. 32. ed. São Paulo: Malheiros, 2009. 
SINTOMER, Yves. O Poder ao povo: júris de cidadãos, sorteio e democracia participativa. Tradução de André Rubião. Belo Horizonte: UFMG, 2010.

SOUZA, Murilo. Câmara Notícias.14 partidos não alcançam cláusula de desempenho e perderão recursos, disponível em: http://www2.camara.leg.br/camaranoticias/noticias/POLITICA/ 564071-14-PARTIDOS-NAO-ALCANCAM-CLAUSULA-DE-DESEMPENHO-E-PERDERAO-RECURSOS. html acesso em 10 out. 2018.

TAVARES, José Antônio Giusti. Sistemas eleitorais nas democracias contemporâneas: teorias, instituições e estratégia. Rio de Janeiro: Relume-Dumará, 1994.

TOQUEVILLE, Alexis de. A democracia na América: leis e costumes de certas leis e certos costumes políticos que foram naturalmente sugeridos aos americanos por seu estado social e cronologia de François Furet. Tradução de Eduardo Brandão. V. I. 2. ed. São Paulo: Martins Fontes, 2005.

VILLAS BOAS, Marco Anthony Steverson. A Cláusula de Barreira no Direito Brasileiro. Revista do Instituto do Direito Brasileiro, Ano 2, n. 8, 2013. Disponível em: <http://www.cidp.pt/publicacoes/revistas/ridb/2013/08/2013_08_08891_08980.pdf>. Acesso em: 05 nov. 2017.

WEBER, Max. A Política como vocação. Tradução de Mauricio Tragtenberg. Brasília: Universidade de Brasília, 2003.

ZAKARI, Fareed. The rise of illiberal democracy. Disponível em: $<$ https://www.foreignaffairs. com/articles/1997-11-01/rise-illiberal-democracy>. Acesso em 13.08.2018. 